\title{
Field relations, geochemistry, and age of Paleoproterozoic igneous rocks in the northeastern Kaipokok Bay area, Makkovik Province, Labrador
}

\author{
SAndra M. Barr, ${ }^{1 *}$ Chris E. White, and JohnW.F. Ketchum ${ }^{3}$ \\ 1. Department of Earth and Environmental Science, Acadia University, Wolfville, Nova Scotia B4P 2R6, Canada \\ 2. Department of Natural Resources, P.O. Box 698, Halifax, Nova Scotia B3J 2T9, Canada \\ 3. Northwest Territories Geoscience Office, P.O. Box 1500,Yellowknife, Northwest Territories X1A 2R3, Canada \\ *Corresponding author: <sandra.barr@acadiau.ca $>$
}

Date received: 27 July 2007 Date accepted: 29 October 2007

\begin{abstract}
The northeastern part of Kaipokok Bay is located in the Makkovik Province of Labrador, in the boundary zone between the Kaipokok and Aillik domains. The Kaipokok domain is characterized by reworked Archean gneiss, ca. $2100 \mathrm{Ma}$ mafic metavolcanic and supracrustal metasedimentary rocks, and ca. 1895-1870 Ma plutonic rocks. The Aillik domain to the southeast is characterized by metavolcanic and metasedimentary rocks of the ca. 1860 Ma Aillik Group and younger $1800 \mathrm{Ma}$ (syn-Makkovikian), $1720 \mathrm{Ma}$ (post-Makkovikian), and 1670-1640 Ma (Labradorian) plutonic rocks. In the study area, the Aillik Group is dominated by metasandstone with less abundant metaconglomerate and meta-rhyolite, and rare calc-silicate and mafic volcanic rocks. The largest plutons in the area are the ca. 1802 Ma Long Island Quartz Monzonite and Kennedy Mountain granite, part of the Kennedy Mountain Intrusive Suite of the Aillik domain. A U-Pb (zircon) age of 1800.6 $\pm 2.3 \mathrm{Ma}$ for the Kennedy Mountain granite confirms that it is the same age as the Long Island Quartz Monzonite, as inferred by earlier workers in the area. Plutons of similar age (Drunken Harbour and Hares Islands granites) have been documented farther northwest in the Kaipokok domain. The presence of compositionally similar 1800 Ma plutons in both the Aillik and Kaipokok domains is consistent with tectonic models which show that the domains were juxtaposed by that time. These plutons have within-plate, A-type characteristics, and were likely emplaced during regional transpression that was focussed on the Kaipokok Bay shear zone between the Kaipokok and Aillik domains. Labradorian-age (1670-1640 Ma) plutonic rocks occur in both the Kaipokok and Aillik domains and range in composition from ultramafic to gabbro and granite. These plutons have diverse petrological characteristics and their ages are not well constrained. Their tectonic setting during emplacement is uncertain, as they are located far from the focus of Labradorian orogenic activity in the Grenville Province.
\end{abstract}

RÉSUMÉ

La partie nord-ouest de la baie de Kaipokok est située dans la province de Makkovik au Labrador, à l'intérieur de la zone bordière séparant les domaines de Kaipokok et d'Aillik. Le domaine de Kaipokok se caractérise par la présence de gneiss archéen, de roches métasédimentaires supracrustales et métavolcaniques mafiques d'environ $2100 \mathrm{Ma}$, ainsi que de roches plutoniques ayant environ 1895 à 1870 Ma. Le domaine d'Aillik au sud-est est caractérisé par des roches métavolcaniques et métasédimentaires du groupe d'environ 1860 Ma d'Aillik et des roches plutoniques plus récentes de $1800 \mathrm{Ma}$ (synmakkovikiennes), de $1720 \mathrm{Ma}$ (post-makkovikiennes) et de 1670 à $1640 \mathrm{Ma}$ (labradoriennes) plutoniques. Dans le secteur d'étude, le groupe d'Aillik est principalement composé de métagrès et d'une quantité moins abondante de métaconglomérat et de métarhyolite, ainsi que de rares roches volcanomafiques et silicates calciques. Les plutons les plus volumineux dans le secteur sont l'adamellite de l'île Long d'environ 1802 Ma et le granite du mont Kennedy, qui fait partie du cortège intrusif du mont Kennedy du domaine d'Aillik. Une datation U-Pb (zircon) de 1800,6 \pm 2,3 Ma du granite du mont Kennedy confirme qu'il a le même âge que l'adamellite de l'île Long, comme l'avaient supposé des chercheurs antérieurs dans le secteur. Des plutons d'un âge similaire (granite de Drunken Harbour et des îles Hares) ont été documentés plus au nord-ouest dans le domaine de Kaipokok. La présence de plutons de $1800 \mathrm{Ma}$ de composition analogue dans les domaines d'Aillik et de Kaipokok est conforme aux modèles tectoniques montrant que les domaines étaient juxtaposés à cette époque. Ces plutons possèdent les caractéristiques du type $\mathrm{A}$ intra-plaque; ils se sont probablement mis en place au cours de la transpression régionale qui était vraisemblablement concentrée sur la zone de cisaillement de la baie de Kaipokok, entre les domaines de Kaipokok et d'Aillik. Des roches plutoniques remontant au Labradorien (1670 - 1640 Ma) sont présentes dans les domaines de Kaipokok et d'Aillik; 
leur composition varie des roches ultramafiques au gabbro et au granite. Ces plutons présentent des caractéristiques pétrologiques diversifiées et leurs âges ne sont pas bien définis. On ignore quel était exactement leur milieu tectonique pendant leur mise en place, car elles se trouvent loin du foyer de l'activité orogénique labradorienne à l'intérieur de la province de Grenville.

\section{[Traduit par la redaction]}

\section{INTRODUCTION}

The northeastern Kaipokok Bay area straddles the boundary between the Kaipokok and Aillik domains of the Makkovik Province in Labrador (Fig. 1). Geological mapping and structural, chronological, and petrological studies were done in coastal parts of the Makkovik Province in the late 1990s as part of supporting geoscience projects related to the offshore Lithoprobe ECSOOT transect (e.g., Hall et al. 1995; Ketchum et al. 1997, 2001a, b, 2002; Culshaw et al. 2000; Barr et al. 2001; Sinclair et al. 2002). The petrological studies focused on the Island Harbour Bay area of the Kaipokok domain (Barr et al. 2001) and on the Makkovik area of the Aillik domain (Sinclair et al. 2002), but petrological data from igneous and metaigneous units in the intervening northeastern Kaipokok Bay area (Fig. 1b) were not included. This paper fills that gap by presenting previously unpublished field and petrological data from the northeastern Kaipokok Bay area, and fitting them into the regional geological context. The documentation of these results is timely because of increased interest in uranium and base metal potential in the area, which has resulted in renewed exploration activity and related geological investigations (e.g., Hinchey 2007a, b).

\section{REGIONAL GEOLOGICAL SETTING}

The Kaipokok domain of the Makkovik Province consists of reworked Archean gneiss of the Nain Province and remnants of an overlying cover sequence of Paleoproterozoic metavolcanic and metasedimentary strata (e.g., Post Hill Group; Fig. 1b). These units have been intruded by large granitoid plutons of the 1895-1870 Ma Island Harbour Bay Plutonic Suite, interpreted to have been emplaced in an Andean-type setting during dextral transpression, as well as scattered younger plutons (e.g., Ermanovics 1993; Kerr 1994; Kerr et al. 1996, 1997; Culshaw et al. 2000; Barr et al. 2001; Ketchum et al. 2002).

The Kaipokok domain is separated from the Aillik domain to the south and southeast by a series of complex shear zones that are centred on Kaipokok Bay and collectively termed the Kaipokok Bay shear zone (Fig. 1a, b; Culshaw et al. 2002). The Aillik domain is dominated by metavolcanic and metasedimentary rocks of the Aillik Group (formerly Upper Aillik Group; Ketchum et al. 2002) (Fig. 1). The contact between the Aillik Group and the Post Hill Group (formerly Lower Aillik Group; Ketchum et al. 2002) of the Kaipokok domain is highly tectonized within the Kaipokok Bay shear zone, and stratigraphic relations cannot be demonstrated (Kerr et al. 1996, 1997; Culshaw et al. 2000, 2002; Ketchum et al. 2002).
Structures in the western part of the Aillik Group suggest that it was thrust westward onto the Post Hill Group and associated Archean basement (Clark 1979; Culshaw et al. 2000, 2002). In the type area around Makkovik Bay, the Aillik Group has been interpreted to consist of an earlier, dominantly sedimentary sequence, including arkosic sandstone, bedded tuff, siltstone, conglomerate, and minor mafic to felsic volcanic rocks, and a younger, dominantly volcanic sequence of dacitic to rhyolitic tuffs and flows with minor volcaniclastic sedimentary rocks (Bailey 1981; Gandhi et al. 1969; Gandhi 1978; Gower et al. 1982; Gower and Ryan 1987; Kerr 1994; Sinclair et al. 2002). However, in the light of her new mapping, Hinchey (2007b) noted that it is unlikely that the concept of early and late sequences is valid. She advocated a more regional view, suggesting that the Cape Aillik area is dominated by sedimentary rocks with minor felsic volcanic components, and that the Makkovik Bay area to the southeast is dominated by felsic and mafic volcanic rocks with less abundant sedimentary units, a view consistent with the data presented below. The age of the Aillik Group is somewhat equivocal, but generally accepted to be at least in part about $1860 \mathrm{Ma}$ (see discussion in Sinclair et al. 2002, Ketchum et al. 2002, and Hinchey 2007b).

Abundant plutons are present in the Aillik domain, and have yielded U-Pb ages of about $1800 \mathrm{Ma}, 1720 \mathrm{Ma}$, and 1650-1640 $\mathrm{Ma}($ Kerr 1994; Kerr et al. 1992, 1996). Most of the ca. $1800 \mathrm{Ma}$ plutons are foliated and hence considered syntectonic with the "Makkovikian orogeny" that deformed their host rocks. The unfoliated ca. 1720 and 1650 Ma plutons are termed post-tectonic Makkovikian and Labradorian, respectively, in the latter case because the ages broadly coincide with the Labradorian orogeny of the Grenville Province to the south (Kerr et al. 1992; Kerr 1994). Laser-ablation data have suggested that at least some of the $1720 \mathrm{Ma}$ suite may be younger (about $1660 \mathrm{Ma}$ ) and the apparent $1720 \mathrm{Ma}$ age is the result of mixing between zircon of Labradorian age and inherited older (1800-1850 Ma) zircon grains ( Cox et al. 2003).

The Cape Harrison domain, located south and southeast of the Aillik domain, is dominated by ca. $1800 \mathrm{Ma}, 1720 \mathrm{Ma}$, and especially 1650 Ma plutonic suites, similar to those in the Aillik domain, and the boundary between the two domains is obscured by these younger plutons (Gower and Ryan 1986; Kerr et al. 1992, 1996). The Cape Harrison domain includes the Cape Harrison Metamorphic Suite, a package of tonalitic, granodioritic, and granitic orthogneiss intruded by varied foliated and unfoliated granitoid rocks. Although the gneissic rocks resemble reworked Archean gneiss of the Kaipokok domain, $\mathrm{U}-\mathrm{Pb}$ (zircon) dating yielded an age of about $1815 \mathrm{Ma}$, and positive epsilon $\mathrm{Nd}$ values indicate that the gneiss and associated granitoid rocks represent juvenile material (Kerr and Fryer 


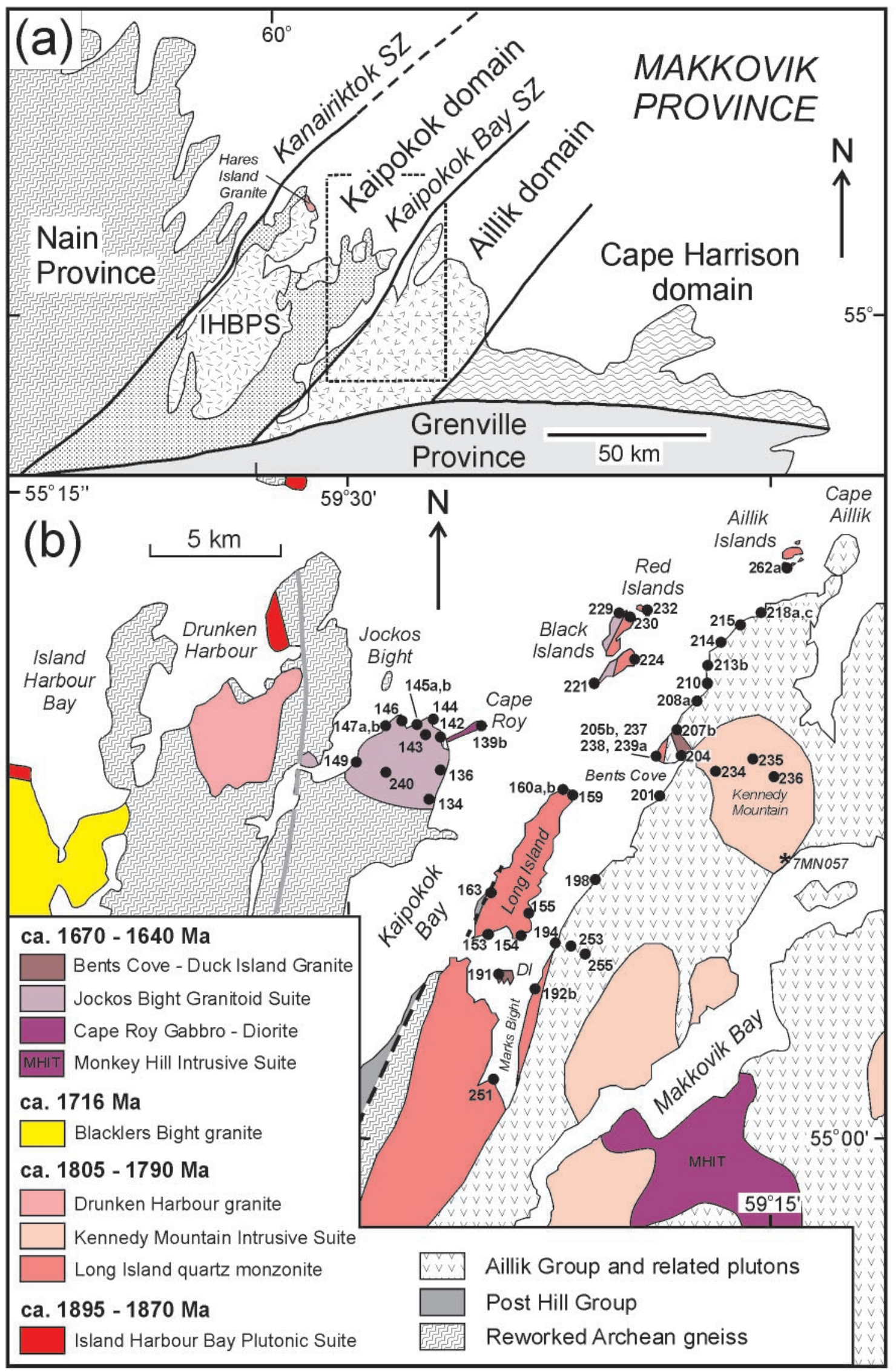

Fig. 1 (a) Location of the Makkovik Province, Labrador, located between the Nain and Grenville provinces and consisting of the Kaipokok, Aillik, and Cape Harrision domains. (b) Geological map of the Kaipokok Bay area, Makkovik Province, Labrador (after Ketchum et al. 2002 and references therein). Areas of Post Hill Group on Black and Red islands are too small to show at this scale. Abbreviation DI indicates Duck Island. Sample locations are plotted using the last 3 digits of the sample numbers in Table 1. Asterisk indicates location for dated Kennedy Mountain granite sample 7MN057. 
1994; Ketchum et al. 2002). The Cape Harrison Metamorphic Suite may represent an exotic terrane accreted to the Makkovik orogen by about $1.8 \mathrm{Ga}$ (Ketchum et al. 2002).

\section{FIELD RELATIONS IN THE NORTHEASTERN KAIPOKOK BAY AREA-AN OVERVIEW}

The western part of the Kaipokok Bay area is dominated by reworked Archean gneiss and ca. 2100 Ma mafic metavolcanic and metasedimentary rocks of the Post Hill Group (Ketchum et al. 2001b, 2002). During the present study, amphibolite, mafic schist, and metasedimentary rocks of the Post Hill Group were observed also on the western shore of Long Island, on the Black Islands, and on the Red Islands, consistent also with the new mapping of Hinchey (2007b). These rocks of the Post Hill Group are separated by shear zones, plutonic units, and/or water from metavolcanic and metasedimentary rocks of the Aillik Group which characterize the Aillik domain (Fig. 1b). Plutonic rocks of the 1895-1870 Ma Island Harbour Bay Plutonic Suite occur only in the Kaipokok domain (Fig. 1a), whereas the younger plutonic rocks which are the focus of this paper occur in both the Kaipokok and Aillik domains (Fig. 1b). Names and ages assigned here to the younger plutonic units generally follow Kerr (1994), except where modifications are required as a result of field and petrological observations made during the present study, as described below.

Kerr (1994) recognized several suites of about $1800 \mathrm{Ma}$ plutons in the Kaipokok Bay area, which he considered to be syn-tectonic with the Makkovikian orogeny, an event interpreted by subsequent workers to be linked possibly to docking of the Cape Harrison domain against the Aillik and Kaipokok domains (Culshaw et al. 2002; Ketchum et al. 2002). In the study area (Fig. 1b), these units include the Long Island Quartz Monzonite and Kennedy Mountain granite (part of the Kennedy Mountain Intrusive Suite of Kerr 1994). The Drunken Harbour Granite in the Kaipokok domain (Fig. 1b) was included in the Island Harbour Bay Plutonic Suite by Ryan et al. (1983) and Kerr (1994), but based on its igneous crystallization age of $1792 \pm 2 \mathrm{Ma}$ (U-Pb titanite; Ketchum et al. 2001a), as well as petrological features, it is included now with the ca. $1800 \mathrm{Ma}$ units (Fig. 1b; Barr et al. 2001). The petrology of this foliated pluton was described by Barr et al. (2001), and the pluton is included in the present paper only for comparison.

Kerr (1994) also recognized a suite of post-tectonic, about $1720 \mathrm{Ma}$, Makkovikian plutonic rocks in the Aillik domain although, as noted above, Cox et al. (2003) suggested that the age may be a mixing, rather than intrusive, age. In any case, no plutons of this age appear to be present in the Kaipokok Bay study area, although the $1716 \pm 1$ Ma Blacklers Bight granite farther west in the Kaipokok domain may be related (Ketchum et al. 2001a; Barr et al. 2001). A large number of about 1650$1640 \mathrm{Ma}$ (Labradorian) plutonic rocks are also scattered through the Aillik domain (Kerr 1994; Hinchey 2007b). In the Kaipokok Bay area Kerr (1994) included the Bents Cove and Duck Island granite bodies (Fig. 1b) in the Labradorian
Monkey Hill Intrusive Suite, inferred to have a maximum age of about 1650 Ma based on the fact that it intruded the Adlavik Intrusive Suite, a mainly mafic Labradorian suite from which a dioritic component was dated at $1649 \pm 1 \mathrm{Ma}$ (Kerr et al. 1992). Mapping during the present study showed that, based on their distinctive petrological features, Labradorian rocks are more widespread in the Kaipokok Bay area than recognized by Kerr (1994), and occur in both the Kaipokok and Aillik domains. They include granitoid rocks in the Jockos Bight-Cape Roy area on the west side of Kaipokok Bay, which in the absence of geochronological or petrological data, Gower et al. (1982) and Kerr (1994) had included in the Island Harbour Bay Plutonic Suite. That area is divided here into the Cape Roy GabbroDiorite and Jockos Bight Granitoid Suite (Fig. 1). The Cape Roy Gabbro-Diorite occurs at Cape Roy and at several other locations throughout the study area, which are described in more detail below. Based on similarity in petrological features, it may be part of the Adlavik Intrusive Suite of Kerr (1994). It intruded the Long Island Quartz Monzonite, and was in turn intruded by components of the Jockos Bight Granitoid Suite, which is included here as part of the younger and mainly felsic Monkey Hill Intrusive Suite of Kerr (1994).

The Jockos Bight Granitoid Suite as defined here includes granitic components that are likely equivalent to the Bents Cove granite of Kerr (1994). As also recognized by Hinchey (2007b), the Bents Cove granite in its type area around Bents Cove is less extensive than suggested by Kerr (1994) and Gower et al. (1982). However, the coastal section between Bents Cove and Cape Aillik is a complex assemblage of Aillik Group metasedimentary and metavolcanic rocks intruded by a variety of plutonic rocks that include Long Island Quartz Monzonite, Cape Roy Gabbro-Diorite, Bents Cove granite, and a variety of porphyry, pegmatite, lamprophyre, and mafic dykes. The latter units were not sampled during the present study.

The unnamed minor intrusion of the Monkey Hill suite shown inland to the east from Duck Island by Kerr (1994) was not found during the present study. Mapping in that area suggested that the rocks there are metavolcanic and part of the Aillik Group.

\section{UNIT DESCRIPTIONS}

\section{Aillik Group}

Rocks of the Aillik Group dominate the coastal section between Marks Bight and Cape Aillik (Fig. 1b). The distribution of rock types was not mapped in detail due to time constraints, but the package as a whole appears to contain more sedimentary rocks than the volcanic-dominated exposures of the group in the Makkovik Bay area (Sinclair et al. 2002). This observation is supported by Hinchey (2007b), who mapped most of the Aillik Group in the present study area as tuffaceous and volcaniclastic metasandstone. The sedimentary units include psammitic rocks with relict bedding and, in places, cross-bedding (Fig. 2a) and heterolithic conglomerate (Fig. 2b, c). Clasts in the 

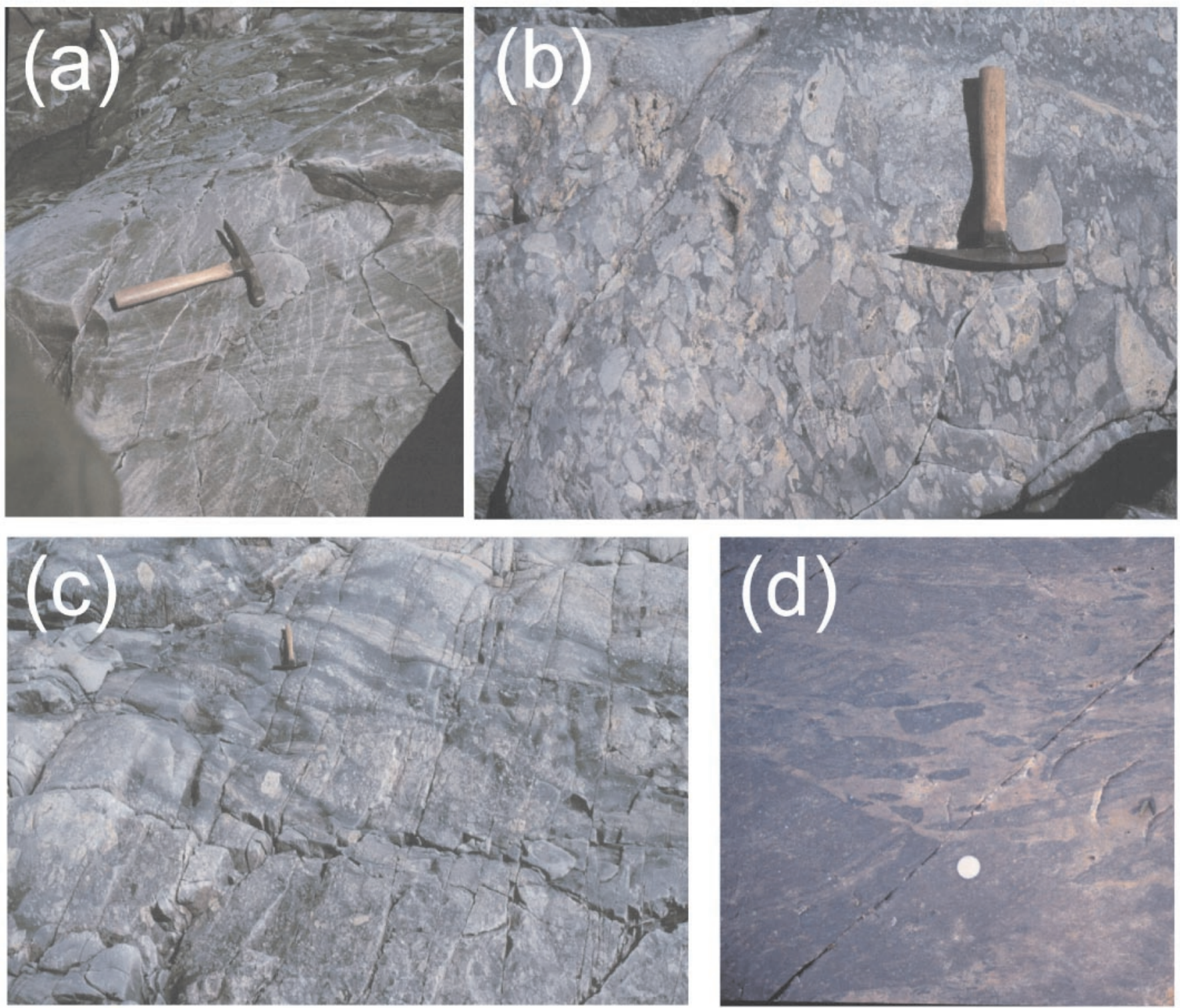

Fig. 2 Outcrop photographs illustrating primary features of the Aillik Group. (a) Psammite with cross-bedding on the coast east of Long Island. (b) Heterolithic breccia with angular to subangular clasts. (c) Heterolithic conglomerate interlayered with psammite. (d) Rhyolitic clasts in an autobreccia or lahar.

conglomerate units include granite, flow-banded and in places spherulitic rhyolite, arkosic sandstone, mafic porphyry, and andesite. No gneissic clasts were seen, and the granitic clasts are not similar in appearance to any of the granitoid units in the area familiar to the authors. In some places coarse chaotic fragmental rocks with angular to ellipsoidal deformed clasts may represent lahar deposits (Fig. 2d). Volcanic rocks in the northeastern Kaipokok Bay area include flow-banded rhyolite and dacite, minor mafic rocks (locally amygdaloidal basalt), and lithic tuff. The rhyolite flows are locally spherulitic and/or amygdaloidal in places. Felsic flows and tuffs are interbedded with psammitic rocks, which in places preserve bedding. Locally on the coast north of Bents Cove, the unit includes marble and calc-silicate rocks. Mineral assemblages suggest that the rocks have been metamorphosed to amphibolite facies, but foliation is generally weakly developed and parallel to bedding where visible. Bedding and foliation trends generally $010^{\circ}$ to $030^{\circ}$, and dips moderately or steeply to the west or northwest. Where discernible, cross-bedding indicates younging to the west. Locally a strong lineation is present at about $345^{\circ}$ with plunges of about $20-30^{\circ}$. In more detailed mapping, Hinchey (2007b) documented regional-scale open folds, especially in the northern part of the coastal section, toward Cape Aillik. The rocks are intruded by abundant cross-cutting granitic pegmatite, as well as porphyry, mafic, and lamprophyre dykes. Granitic dykes and sills are also abundant, as described below.

In thin section, the rocks of the Aillik Group are completely recrystallized; relict megascopic primary igneous and sedimentary features are preserved in outcrop but not in thin section. Most samples have granoblastic textures. Felsic rocks are 
dominated by quartz, microcline, and untwinned plagioclase. Muscovite and biotite are present in some samples. The calcsilicate rock contains calcite, garnet, wollastonite, and clinopyroxene. Mafic rocks are amphibolite, composed of plagioclase, blue-green amphibole, and biotite.

Elsewhere in the Aillik domain, the Aillik Group hosts abundant mineral occurrences, including $\mathrm{Pb}, \mathrm{Zn}, \mathrm{Mo}$, and $\mathrm{U}$ (White and Martin 1980; Wilton 1996). Although areas of alteration are present in the Kaipokok Bay section, no economic mineralization was noted during the present study. However, Hinchey (2007b) noted the presence of covellite and magnetite in pegmatitic granite dykes in the eastern Kaipokok Bay section.

\section{Syn-Makkovikian Plutonic Rocks}

\section{Long Island Quartz Monzonite}

The Long Island Quartz Monzonite (Gower et al. 1982; Kerr 1994) is an elongate body of foliated granitoid rocks that forms most of Long Island and the Marks Bight area to the south (Fig. 1b). It also occurs farther to the southwest of the area shown in Fig. 1b (Kerr 1994). A discordant U-Pb zircon age of 1802 $+13 /-7$ Ma was interpreted to represent the igneous crystallization age, whereas a younger $\mathrm{U}-\mathrm{Pb}$ age from titanite (1746 $\pm 2 \mathrm{Ma}$ ) likely provides a minimum age for deformation and metamorphism of the unit (Kerr et al. 1992).

The Long Island Quartz Monzonite was mapped along the shorelines of Long Island and Marks Bight. Rocks of similar composition were also mapped near Bents Cove, on the eastern parts of the Black Islands, locally along the adjacent parts of the Cape Aillik shoreline, and on the Aillik Islands west of Cape Aillik (Fig. 1b). On the point of land west of Marks Bight, the contact with gneissic rocks to the west appears to be intrusive, with the quartz monzonite chilled against the gneiss. However, on the western side of Long Island, and on the Black Islands, the exposed contacts with metavolcanic rocks (Post Hill Group) of the Kaipokok domain are sheared, part of the Kaipokok Bay shear zone of Culshaw et al. (2000, 2002), and the Long Island Quartz Monzonite is mylonitic in this area. No Long Island Quartz Monzonite was found in the Kaipokok domain, although the Hares Islands granite (Fig. 1a) is of similar age. The contact with the Aillik Group on the mainland east of Long Island also appears to be faulted, although monzonitic rocks interpreted to be linked to the Long Island Quartz Monzonite occur along the Cape Aillik coast, and in places intruded the Aillik Group.

Internally, the Long Island Quartz Monzonite shows variation in grain size from fine to coarse, and in composition from quartz diorite to monzogranite, in places with sharp contacts between these variants. A characteristic feature in every outcrop is the presence of abundant dioritic xenoliths. Foliation is variably developed, oriented about $170-175^{\circ}$, and dips to the west at $50-80^{\circ}$. The foliation may be related to emplacement of the pluton during motion on the Kaipokok Bay shear zone.

The mineralogy of samples collected during the present study concurs with the description of Kerr (1994). The major minerals are quartz $(10-20 \%)$, plagioclase $(30-50 \%)$, and microcline (20-30\%), with about $10-30 \%$ biotite and amphibole in variable proportions. Accessory phases include magnetite, apatite, titanite, allanite, and zircon. Epidote and chlorite are abundant secondary minerals.

\section{Kennedy Mountain Granite}

The Kennedy Mountain granite forms the Kennedy Mountain area (Fig. 1b, 3a) east of Bents Cove. Kerr (1994) assigned this granite and other granitic units with similar petrological features in the Aillik domain to the Kennedy Mountain Intrusive Suite, which he interpreted to be similar in age to the Long Island Quartz Monzonite (about $1800 \mathrm{Ma}$ ), based on the foliation present in both units. This inference is confirmed by a U-Pb zircon age obtained from sample 7MN057 from the southern part of the granite on the north shore of Makkovik Bay (Fig. 1b). Three fractions, each consisting of 3 or 4 colourless, small prismatic zircon grains lacking cracks or inclusions (Table 1) were analyzed by isotope dilution-thermal ionization mass spectrometry at Memorial University. The three analyses overlap concordia and yield a weighted mean ${ }^{207} \mathrm{~Pb} /{ }^{206} \mathrm{~Pb}$ age of $1800.6 \pm 2.3 \mathrm{Ma}$ (Fig. 4), which is interpreted to be the crystallization age of the Kennedy Mountain granite. This result is the same within error as the age reported by Kerr et al. (1992) for the Long Island Quartz Monzonite.

The Kennedy Mountain granite is coarse-grained and homogeneous. Samples examined during the present study have mineralogy consistent with that described by Kerr (1994) for the Kennedy Mountain suite as a whole. They contain quartz (20-30\%), microcline (25-50\%), and less abundant plagioclase (10-30\%). The mafic minerals form up to $10 \%$ and are both biotite and amphibole. Accessory minerals in these samples are zircon, apatite, allanite, and magnetite. Kerr (1994) described accessory purple fluorite and pegmatite dykes containing amazonite, and such material was observed north and inland from Bents Cove, although it was not clear from field relations if they are hosted by the Kennedy Mountain granite or the Aillik Group. Similar amazonite-bearing pegmatite is associated with the ca. 1716 Ma Blackers Bight Granite in the Kaipokok domain (Barr et al. 2001).

\section{Labradorian Plutonic Rocks}

\section{Cape Roy Gabbro-Diorite}

The distinctive mafic rocks exposed on Cape Roy have petrological features suggesting that they are part of the Adlavik Intrusive Suite of Kerr (1994), which is characterized by rocks ranging from gabbroic to dioritic and includes ultramafic and mafic cumulate rocks and mafic pegmatite. Kerr et al. (1992) reported a U-Pb age of $1649 \pm 1$ Ma for a dioritic component in the Adlavik suite, which is somewhat younger than the ${ }^{40} \mathrm{Ar} /{ }^{39} \mathrm{Ar}$ ages of about $1670-1660 \mathrm{Ma}$ obtained from igneous amphibole in a Cape Roy diorite sample by Culshaw et al. (2002), who interpreted them to indicate the minimum age 
of emplacement. Culshaw et al. (2002) suggested that these Labradorian suites may span a wider time than indicated by previous dating, although more geochronology is needed to better define the ages of these units.

In addition to the mappable body at Cape Roy, these distinctive mafic rocks occur in small areas in the Long Island Quartz Monzonite and on Black and Aillik islands, in areas too small to show on Fig. 1b. They intruded the 1800 Ma Long Island Quartz Monzonite, but are intruded by granite of the Jockos Bight and Bents Cove suites described below. These observations are consistent with the interpretations of Kerr (1994) who noted that the Monkey Hill Intrusive Suite (in which he included Bents Cove granite) intruded the Adlavik suite, although he considered their ages to be similar (about $1640 \mathrm{Ma})$.

In the Cape Roy area, the wide variety of interesting rock types in the Cape Roy Gabbro-Diorite unit is well exposed. Most abundant is hornblende gabbro, with hornblende phenocrysts and abundant inclusions of varied gabbroic and dioritic rocks and rafts of foliated granitoid rocks. Hornblendite layers occur in some areas, as well as patches of dioritic pegmatite with crystals up to several centimetres in length that appear to have formed in miarolitic cavities in the rock. In places, sulphide minerals (pyrite, chalcopyrite) are abundant. In some areas the rocks are leucocratic and almost anorthositic in composition. The mafic rocks are also co-mingled with and net-veined by younger unfoliated granitic rocks that may be related to the Jockos Bight suite described below. These relationships, combined with the chemical data described below, suggest that the Labradorian Adlavik and Monkey Hill suites may overlap in age and composition, and represent a single suite emplaced over a time span of possibly 20-30 Ma.

\section{Jockos Bight Granitoid Suite}

The Jockos Bight suite is well exposed south of Cape Roy and along the shore of Jockos Bight to the west and offshore on the Black and Red islands (Fig. 1b). Rocks assigned to the suite also occur on Long Island where they intruded the Long Island Quartz Monzonite as dykes, sills, and small plutons, too small to show on Figure 1b. The Jockos Bight suite includes a wide range of rock types, with compositions ranging from diorite to granite and textures from fine grained and porphyritic to medium grained to pegmatitic. The granitic and pegmatitic components appear to be the same as the Bents Cove and Duck Island granites and associated pegmatite of Kerr (1994). However, because of the variety of rock types present and their geographic isolation from those other units, and the fact that they intrude Kaipokok domain gneiss in the Jockos Bight area, in this paper we use the new name, Jockos Bight Granitoid Suite, collectively for these rocks. However, like the Bents Cove and Duck Island granites, the Jockos Bight suite is likely part of the Monkey Hill Intrusive Suite.

The coast to the south and north of Cape Roy appears to follow the contact between granite of the Jockos Bight suite and its gneissic host rocks. Apophyses of the granite cut the gneiss, and gneissic and amphibolitic rafts are abundant in the granite, as well as a variety of dioritic xenoliths, mafic schlieren, and crosscutting red granite sills, pegmatite and aplite dykes, and mafic dykes. In places the granite shows weak magmatic layering. In the Jockos Bight coastal section, the above-described granite is the dominant lithology, and intruded grey and red varieties of fine-grained quartz-feldspar porphyritic granite. The red variety of porphyry intruded the grey variety. All three units are intruded by composite mafic and felsic dykes. None of the units are deformed or foliated. Near the contact with gneissic rocks, to the west, gneissic rafts again appear in the granite.

\section{Duck Island Granite}

The Duck Island Granite forms Duck Island and also occurs as abundant dykes and sheets in the Long Island Quartz Monzonite in the area, as noted by Kerr (1994). It also occurs in the coastal section of Kaipokok Bay to the southwest of Long Island where it forms dykes and sills in the Post Hill Group and Kaipokok domain gneiss. It is, therefore, much more abundant in the Kaipokok Bay area than can be depicted on Figure $1 \mathrm{~b}$. The Duck Island Granite is similar to the Bents Cove Granite, and to the granitic component in the Jockos Bight Granitoid Suite. The granite is unfoliated and associated with abundant pegmatite. It is a homogeneous fine- to medium-grained syenogranite, with abundant K-feldspar (microcline).

\section{Bents Cove Granite and other intrusive rocks in the Bents Cove-Cape Aillik section}

The Bents Cove Granite was shown by Gower et al. (1982) and Kerr (1994) as a large body extending from Bents Cove along the shoreline toward Cape Aillik. However, our mapping along the shoreline from Bents Cove to Cape Aillik revealed that metasedimentary and less abundant metavolcanic rocks of the Aillik Group dominate the section, although varied intrusive rocks, including what is termed here the Bents Cove Granite, are almost equally abundant. The granite outcrops in Bents Cove, but farther to the west along the shore, a body of Long Island Quartz Monzonite is present (Fig. 1b). Most of the shoreline to the north is Aillik Group with granitic dykes and sheets of Bents Cove Granite (e.g., Fig. 3b) and a variety of other plutonic rocks (see also Hinchey 2007b).

\section{GEOCHEMISTRY}

\section{Introduction}

For the current study, whole-rock chemical data were obtained from 51 samples (Table 1) representing the units described above. Chemical data from some of these units also were reported by Kerr (1994) and Sinclair (1999), and are plotted for comparison on the chemical diagrams, but not included 

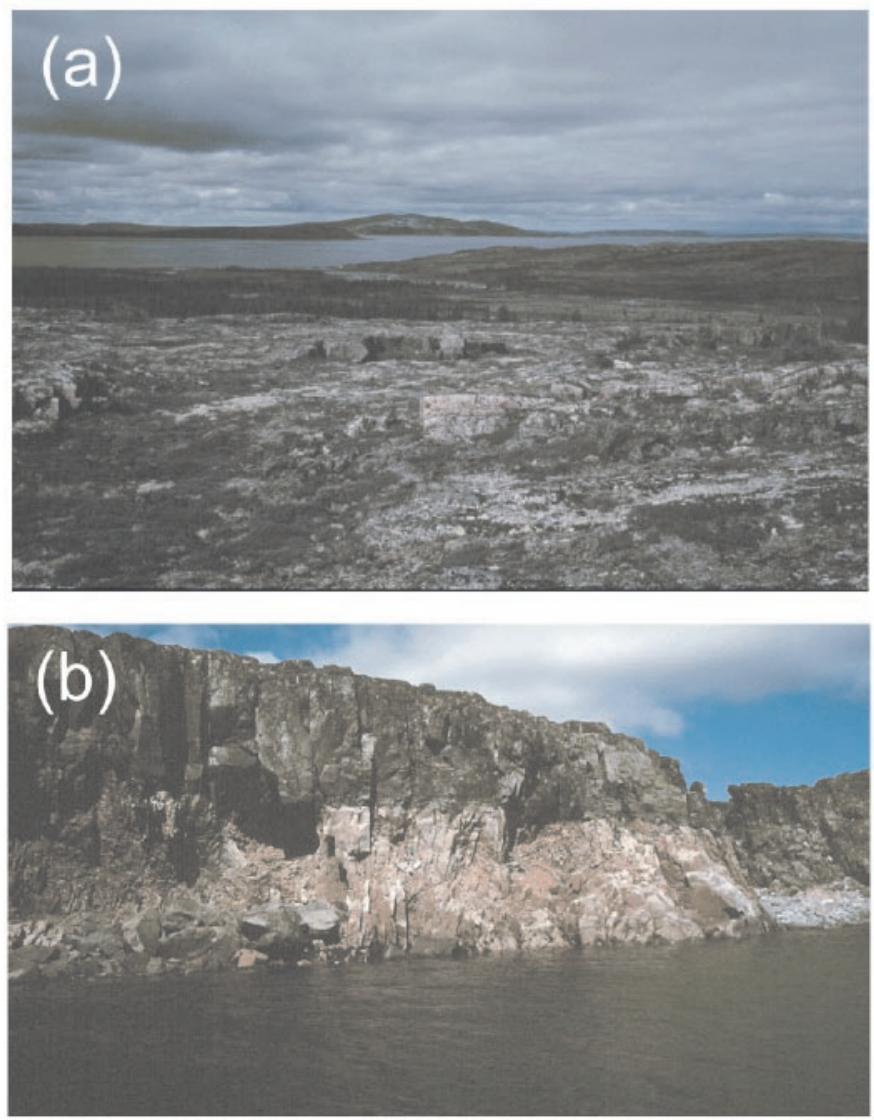

Fig. 3 (a) View to the southwest from the top of Kennedy Mountain, looking across Bents Cove, the northern tip of Long Island, and Kaipokok Bay to the Jockos Bight Granite. Rocks in the foreground are Kennedy Mountain granite. (b) Sill of Bents Cove Granite in the Aillik Group, shore of Kaipokok Bay between Bents Cove and Cape Aillik.

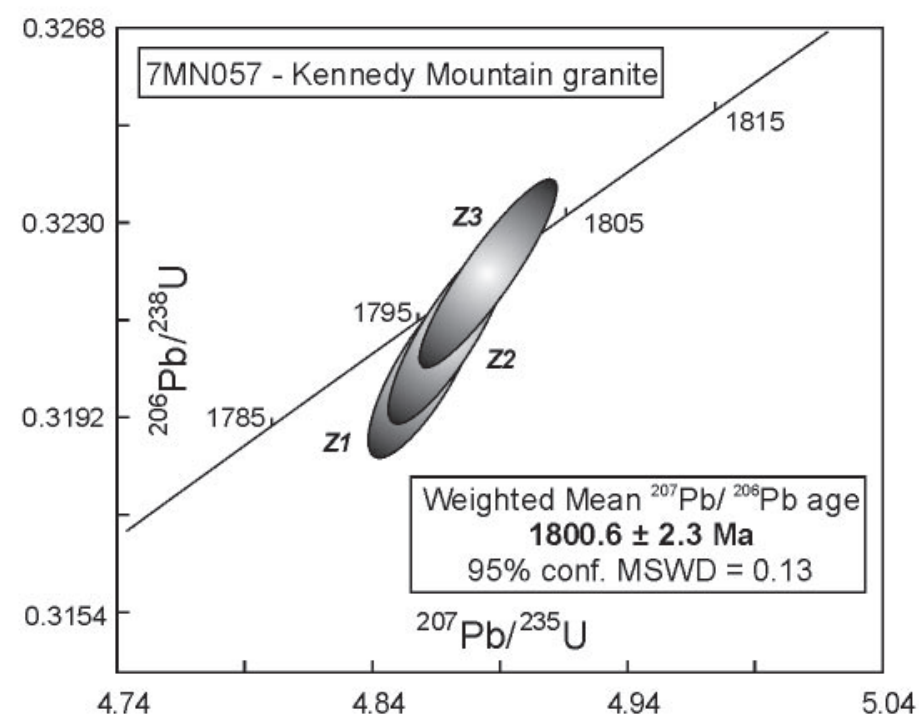

Fig. 4 U-Pb Concordia diagram for sample 7MN057 from the Kennedy Mountain granite. Sample location is indicated on Fig. 1b. Analytical data are shown in Table 1. in Table 1. The diagrams were selected in order to illustrate the chemical variation in these diverse units, and also to provide an indication of chemical affinity and tectonic setting.

\section{Aillik Group}

Analyzed samples from the Aillik Group in the Kaipokok Bay area are from units which appear to be flows, although the degree of recrystallization makes original minerals and textures difficult to interpret in most cases. Based on $\mathrm{Zr} / \mathrm{TiO}_{2}$ ratio and $\mathrm{SiO}_{2}$ content, four of the samples are basaltic to andesitic, and five of the samples are rhyodacite to rhyolite (Fig. 5a). Aillik Group samples from the Makkovik Bay area to the east show a similar bimodal distribution (Sinclair 1999; Sinclair et al. 2002). The basaltic and andesitic samples plot in the overlapping island arc-tholeiite - MORB - calc-alkalic basalt fields on the Ti-Zr-Y discrimination diagram (Fig. 5b), as do the majority of mafic samples analyzed by Sinclair et al. (2002). The felsic samples plot on the boundary between volcanic-arc and within-plate fields, whereas the samples from the Makkovik Bay area are more definitively "within-plate" (Fig. $5 \mathrm{c}$ ), although the small number of samples in the present study may not be representative. Relatively high $\mathrm{Ga} / \mathrm{Al}$ ratios and zirconium contents suggest A-type affinity (Fig. 5d). Hence the tectonic setting for the Aillik Group is somewhat ambiguous, with inconsistency between the mafic and felsic components, although Sinclair et al. (2002) considered that a rifted arc setting is most likely. A larger and more regional chemical database is needed in order to more reliably constrain the tectonic setting of the Aillik Group.

\section{Long Island Quartz Monzonite}

Thirteen samples from the Long Island Quartz Monzonite were analyzed during the present study, and an additional 13 samples were reported in Kerr (1994). The samples show a relatively narrow range in composition, considering the heterogeneous appearance of the unit and its abundant xenoliths. With the exception of two more dioritic samples, the samples contain between $62 \%$ and $65 \% \mathrm{SiO}_{2}$ (Fig. 6). They show major element trends typical of calc-alkalic granitoid suites, such as negative correlation of $\mathrm{TiO}_{2}$ and $\mathrm{Fe}_{2} \mathrm{O}_{3}{ }^{\mathrm{t}}$ (Fig. 6a, c) and positive correlation of $\mathrm{K}_{2} \mathrm{O}$ (Fig. 6e) with $\mathrm{SiO}_{2} \cdot \mathrm{Al}_{2} \mathrm{O}_{3}$ and $\mathrm{Na}_{2} \mathrm{O}$ are more or less constant at about $15-16 \%$ and $4 \%$, respectively (Fig. 6b, d). Overall, the unit has high $\mathrm{Ba}$, up to $1761 \mathrm{ppm}$, moderate $\mathrm{Y}$ (about 40 ppm), and U up to 6 ppm (Fig. 6f, g, h). The samples span the boundary between the volcanic-arc and within-plate granite fields (Fig. 7a), and Zr contents mostly in excess of 200 ppm suggest the possibility of A-type affinity (Fig. 7b).

\section{Kennedy Mountain Granite}

Only 3 samples from the Kennedy Mountain Granite were analyzed in the present study (Table 1), but analyses of 19 samples were reported by Kerr (1994) and 6 samples by Sinclair (1999). All of the samples have high $\mathrm{SiO}_{2}$, in the order 
of $74-77 \%$ (Fig. 6). More immobile major elements such as $\mathrm{TiO}_{2}, \mathrm{Al}_{2} \mathrm{O}_{3}$, and $\mathrm{Fe}_{2} \mathrm{O}_{3}{ }^{\mathrm{t}}$ are uniformly relatively low (Fig. 6a, b, c) but mobile elements such as $\mathrm{Na}_{2} \mathrm{O}, \mathrm{K}_{2} \mathrm{O}$, and $\mathrm{Ba}$ show a wide range in concentration, as does $\mathrm{Y}$ (Fig. $6 \mathrm{~d}, \mathrm{e}, \mathrm{f}, \mathrm{g}$ ). U is low $(\leq 5 \mathrm{ppm})$ in all analyzed samples (Fig. $6 \mathrm{~h})$. Most samples plot in the within-plate granite field (Fig. 7a), and have elevated Zr, consistent with A-type affinity.

Also shown for comparison on the diagrams are data for granite units located farther west in the Kaipokok domain that are similar in age (about $1800 \mathrm{Ma}$ ) to the Kennedy Mountain granite: the ca. 1791 Ma Drunken Harbour granite and ca. 1805 Ma Hares Islands granite (Fig. 1). The Hares Islands granite shows the most chemical similarity to the Kennedy Mountain granite, although the analyzed samples show less variation and generally have higher Ba and lower Y (Fig. 6). The Drunken Harbour granite tends to be intermediate in composition between these granites and the Long Island Quartz Monzonite, and the samples generally form reasonably continuous trends, except in Y which is low in the Drunken Harbour samples (Fig. $6 \mathrm{~g})$. All samples show tendency toward within-plate setting and A-type granite chemical affinity (Fig. 7a, b). It may be that all of these units are genetically related and formed in response to similar tectonic conditions, probably late- or post-orogenic regional extension, even though they occur over a wide area.

Also shown for comparison on Figs. 6 and 7 are samples from the Blacklers Bight Granite. Dated at about $1716 \mathrm{Ma}$ (Barr et al. 2002), this pluton is younger than the Kennedy Mountain granite, but has some petrographic similarities as described above. It also has chemical similarities, generally overlapping the Kennedy Mountain and Hares Islands granite samples, except for notably higher $\mathrm{U}$ (Fig. 6h) and $\mathrm{Rb}$ (Fig. 7a).

\section{Cape Roy Gabbro-Diorite}

Because of the wide variation in rock types and their typically coarse-grained and heterogeneous (cumulate) textures, it was not possible to adequately sample the Cape Roy mafic suite for chemical analysis during this reconnaissance study. Only one leucogabbro sample was analyzed, and it has about $47 \% \mathrm{SiO}_{2}$. Its high plagioclase content is reflected in the high $\mathrm{Al}_{2} \mathrm{O}_{3}$ (Fig. 8b) and high $\mathrm{CaO}$ (9.27\%; Table 1). Other notable chemical features include high $\mathrm{Cu}(108 \mathrm{ppm})$ and $\mathrm{Ni}(201 \mathrm{ppm})$ compared to the other analyzed samples (Table 1). These elevated metal values are consistent with the abundant sulphide minerals observed in these rocks.

\section{Jockos Bight Granitoid Suite}

Sixteen samples were analyzed from the Jockos Bight suite, representing the range of rock types observed. They vary from a tonalitic sample with $51.3 \% \mathrm{SiO}_{2}$ through to a granitic sample with almost $74 \% \mathrm{SiO}_{2}$ (Fig. 8). Intermediate samples dominated by plagioclase have the highest $\mathrm{Al}_{2} \mathrm{O}_{3}$ (Fig. 8b), $\mathrm{Na}_{2} \mathrm{O}$ (Fig. 8d), and $\mathrm{Ba}$ (Fig. 8f) contents, whereas mafic samples have the highest contents of $\mathrm{TiO}_{2}$ (Fig. 8a), $\mathrm{Fe}_{2} \mathrm{O}_{3}{ }^{\mathrm{t}}$ (Fig. 8b), and $\mathrm{MgO}$ (Table 1). $\mathrm{K}_{2} \mathrm{O}$ shows positive correlation with $\mathrm{SiO}_{2}$ 

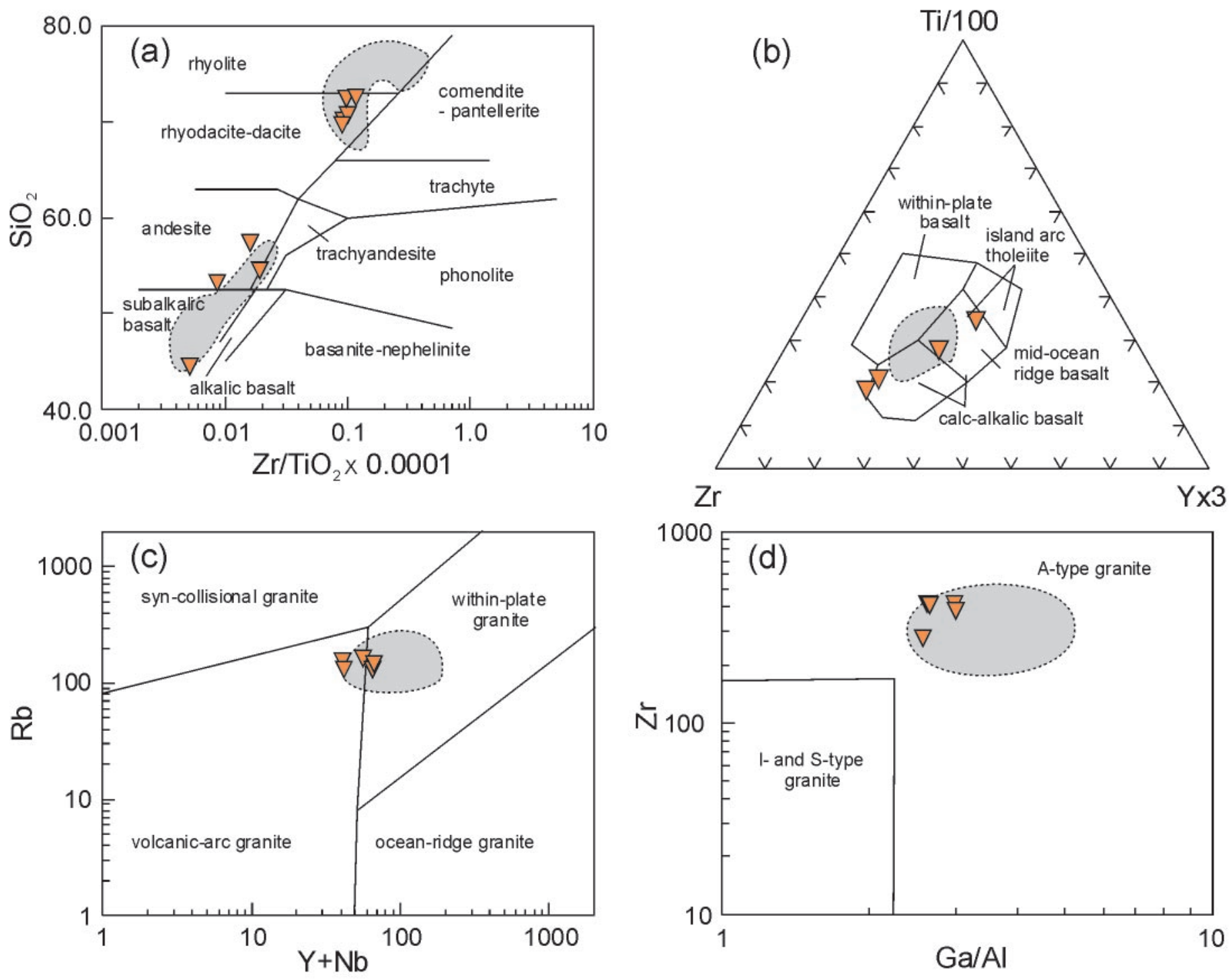

Fig. 5 (a) Samples from the Aillik Group in the Kaipokok Bay area plotted on the $\mathrm{Zr} / \mathrm{TiO}_{2}$ versus $\mathrm{SiO}_{2}$ diagram of Winchester and Floyd (1977). The shaded fields enclose most samples from the Aillik Group in the Makkovik area from Sinclair (1999) for comparison. (b) Mafic samples from the Aillik Group in the Kaipokok Bay area plotted on the Ti-Zr-Y tectonic setting discrimination diagram of Pearce and Cann (1973). The shaded field encloses most mafic samples from the Aillik Group in the Makkovik area from Sinclair (1999) for comparison. (c) Felsic samples from the Aillik Group in the Kaipokok Bay area plotted on the $\mathrm{Y}+\mathrm{Nb}$ versus $\mathrm{Rb}$ tectonic setting discrimination diagram of Pearce et al. (1984). The shaded field encloses most felsic samples from the Aillik Group in the Makkovik area from Sinclair (1999) for comparison. (d) Felsic samples from the Aillik Group in the Kaipokok Bay area plotted on the Ga/Al versus Zr discrimination diagram of Whalen et al. (1987). The shaded field encloses most felsic samples from the Aillik Group in the Makkovik area from Sinclair (1999) for comparison.

(Fig. 8e). A group of samples with higher Y stands out from the remaining samples (Fig. 8g). These samples are from the grey and red porphyry units intruded by the granitic unit. These same porphyry samples tend to cluster on the other chemical diagrams as well, although the differences are not as apparent. Most of these porphyry samples also have elevated U contents, up to $9 \mathrm{ppm}$, whereas most other samples have $U$ below the
XRF detection limit of $1 \mathrm{ppm}$ (Fig. $8 \mathrm{~h}$ ). The porphyry samples plot in the within-plate granite field, whereas the other samples appear to have formed in a volcanic-arc setting (Fig. 9a). They also have more definite A-type granite character because of their high $\mathrm{Zr}$ and $\mathrm{Ga} / \mathrm{Al}$ ratios (Fig. 9b). These porphyry units were not observed in other parts of the Kaipokok Bay study area, and their age, other than being older than the inferred 

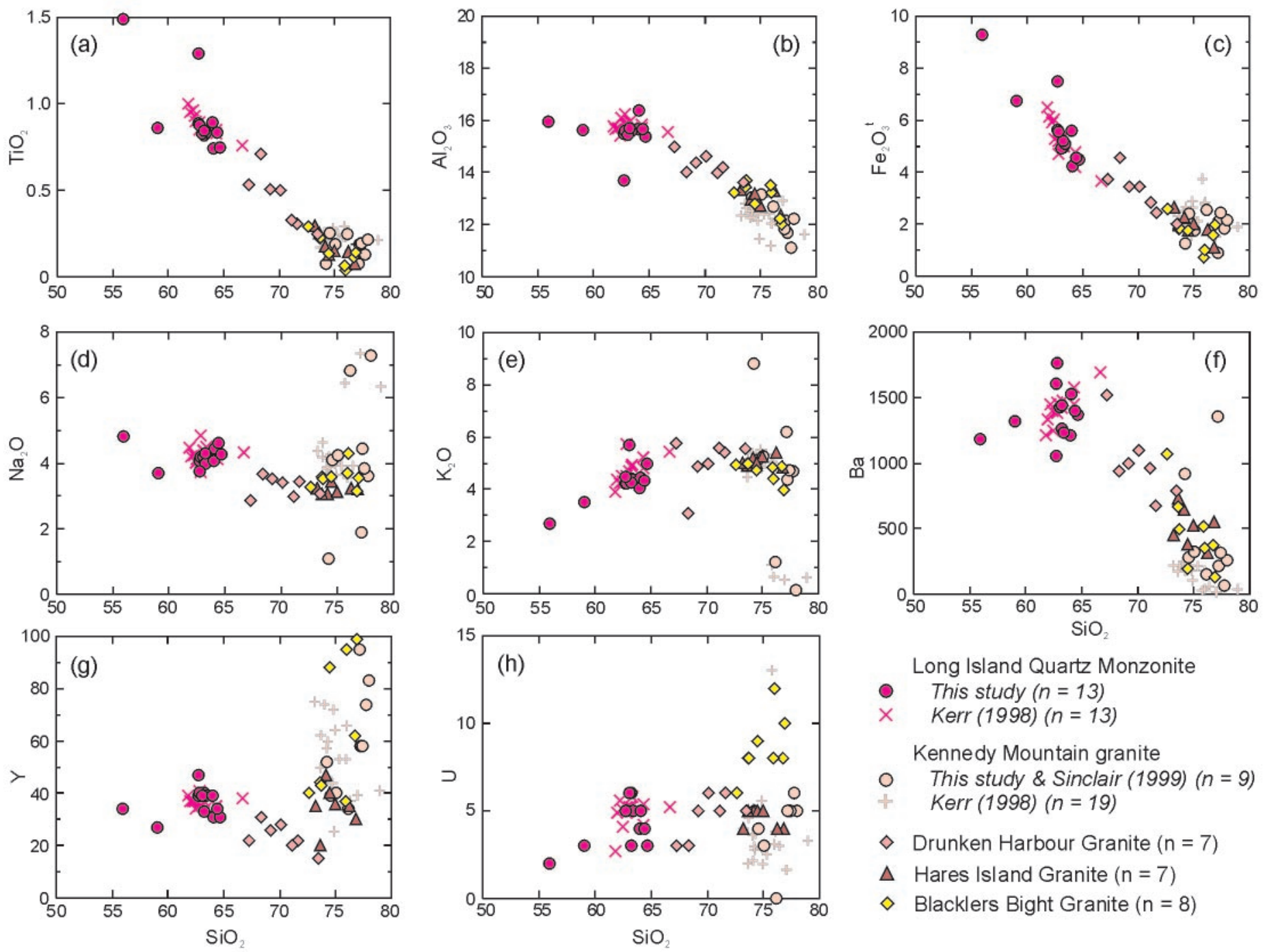

Fig. 6 Plots of $\mathrm{SiO}_{2}$ versus $(\mathrm{a}) \mathrm{TiO}_{2}$, (b) $\mathrm{Al}_{2} \mathrm{O}_{3},(\mathrm{c}) \mathrm{Fe}_{2} \mathrm{O}_{3}{ }^{\mathrm{t}}$, (d) $\mathrm{Na}_{2} \mathrm{O}$, (e) $\mathrm{K}_{2} \mathrm{O}$, (f) $\mathrm{Ba}$, (g) $\mathrm{Y}$, and (h) $\mathrm{U}$ for samples from the Long Island Quartz Monzonite and Kenndy Mountain granite. Data from Drunken Harbour Granite, Hares Islands Granite, and Blacklers Bight Granite in the Island Harbour Bay area of the Kaipokok domain from Barr et al. (2001) are shown for comparison.

1640 Ma granite, is unconstrained, although their lack of deformation suggests that they are younger than the ca. 1800 Ma granitoid units.

\section{Bents Cove Granite}

The granitic rocks along the coastal section between Bents Cove and Cape Aillik are included in this unit, even though they are not readily distinguishable from the granite in the Jockos Bight suite. This mineralogical and textural similarity is borne out by the chemical data which show close similarity to the intermediate and felsic Jockos Bight suite samples (Fig. 8). They are not like the group of high Y samples, and plot in the volcanic arc granite field (Fig. 9a), and relatively low Zr suggest only transitional to A-type character. The analyses by Kerr (1994) are generally in agreement with the analyses obtained in the present study, although the $\mathrm{Zr}$ data seem to be lower than in the analyses obtained during the present study. More analyses are necessary in order to investigate whether these differences are real or related to an analytical problem such as incomplete zircon dissolution.

\section{Duck Island Granite}

Only two samples from the Duck Island granite were analyzed in the present study, although Kerr (1994) reported data for an additional eight samples. Overall, the analyses are very similar to the Bents Cove Granite and the granitic rocks of the Jockos Bight suite (Fig. 8). They contain elevated uranium (Fig. 8h) and plot in the volcanic-arc granite field (Fig. 9a). Data from Kerr (1994) shows generally lower Zr and Ga/Al ratio (Fig. 9b). The similarity in chemical compositions and their generally 

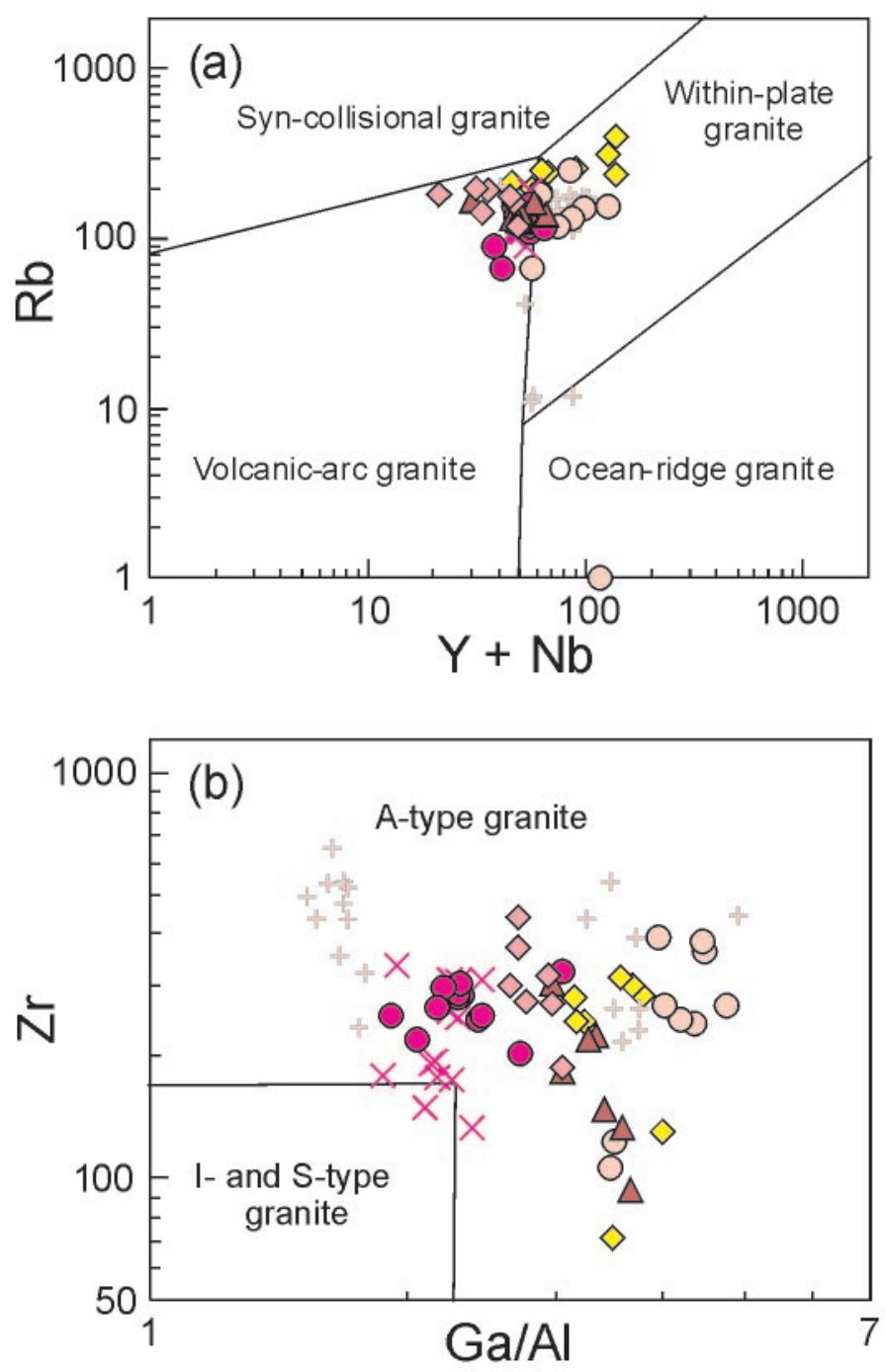

Fig. 7 Plots of (a) $\mathrm{Y}+\mathrm{Nb}$ versus $\mathrm{Rb}$ and (b) Ga/Al versus $\mathrm{Zr}$ for samples from the Long Island Quartz Monzonite and Kenndy Mountain granite. Data from units in the Island Harbour Bay area from Barr et al. (2001) are shown for comparison. Symbols are as in Fig. 6. Fields in (a) are from Pearce et al. (1984) and in (b) from Whalen et al. (1987).

coherent chemical trends support the observation based on field relations and lithologic similarities that the Jockos Bight, Bents Cove, and Duck Island granites are all part of the Monkey Hill Intrusive Suite.

\section{DISCUSSION}

The Aillik Group occurs only on the southeastern side of the Kaipokok Bay Shear Zone in the Aillik domain. In the Kaipokok Bay area it is dominated by metasedimentary rocks with minor felsic and even less abundant mafic volcanic rocks. The pres- ence of arkosic sandstone and conglomerate with carbonate rocks is consistent with earlier interpretations (e.g., Wardle and Bailey 1981; Gower et al. 1982) that the rocks were deposited in a shallow marine to continental environment. The conglomerate units contain granitoid clasts from unknown sources, but the absence of gneissic clasts suggests that old basement rocks were not exposed, or absent, when the unit was being formed. Chemical data from volcanic components of the Aillik Group do not provide a definitive indication of the tectonic setting in which it formed, but a within-plate extensional regime seems most likely. This interpretation is consistent with the models of Ketchum et al. (2002) which show the Aillik Group forming in a back-arc developed at about 1860 Ma behind an active arc built on a relatively juvenile substrate. That arc had accreted to the Kaipokok domain by about $1870 \mathrm{Ma}$, as recorded in the emplacement of the Island Harbour Bay Plutonic Suite in the Kaipokok domain.

Accretion of the Cape Harrison arc to the assembled Kaipokok plus Aillik domains at about 1815 to 1800 Ma resulted in deformation and voluminous syn- and post-collisional granitoid plutons, represented in the study area by the Long Island Quartz Monzonite and Kennedy Mountain granite. These plutons have A-type chemical characteristics and were emplaced within or near the Kaipokok Bay shear zone in an overall transpressional and perhaps locally transtensional setting. Less widespread A-type plutons were emplaced later, at 1740-1700 Ma; such rocks do not appear to occur in the northeastern Kaipokok Bay area but are represented by the Blacklers Bight Granite farther west in the Kaipokok domain.

Younger plutonic units, with ages of $1670 \mathrm{Ma}$ and younger (Cape Roy Gabbro-Diorite, Jockos Bight Granitoid Suite, Bents Cove Granite, and Duck Island Granite) appear to be at the fringes of Labradorian plutonic activity that was focussed south of the Makkovik Province in the Grenville Province, and hence such plutons are more abundant in the more proximal Cape Harrison and Aillik domains. In the study area, some of these Labradorian-age units show some arc-like chemical features, such as low $\mathrm{Y}+\mathrm{Nb}$ (Fig. 9a), in contrast with the more clearly within-plate A-type signatures of the older plutonic units. The variations in the data serve to demonstrate the need for further study, especially as the tectonic setting in which these varied rocks formed is obscure, given the distance of the northeastern Kaipokok Bay area from the Labradorian plutons of the Grenville Province to the south.

Isotopic data from igneous units may provide and indication of the nature of basement terranes underlying the Makkovik Province, in particular the extent of Archean gneiss (e.g., Kerr and Fryer 1994; Kerr and Wardle 1997; Barr et al. 2001; Sinclair et al. 2002). These earlier studies suggested that strongly negative epsilon $\mathrm{Nd}$ values are associated with plutons in the Kaipokok domain $\left(\varepsilon_{\mathrm{Ndt}}=-2.5\right.$ or less; Barr et al. 2001), whereas Aiilik domain units are more juvenile (Kerr and Fryer 1994; Sinclair et al. 2002). The plutons of the northeastern Kaipokok Bay area provide an opportunity to test further these ideas, as the $1800 \mathrm{Ma}$ Long Island and Kennedy Mountain suites are confined to the Aillik domain, but petrologically similar 1800 

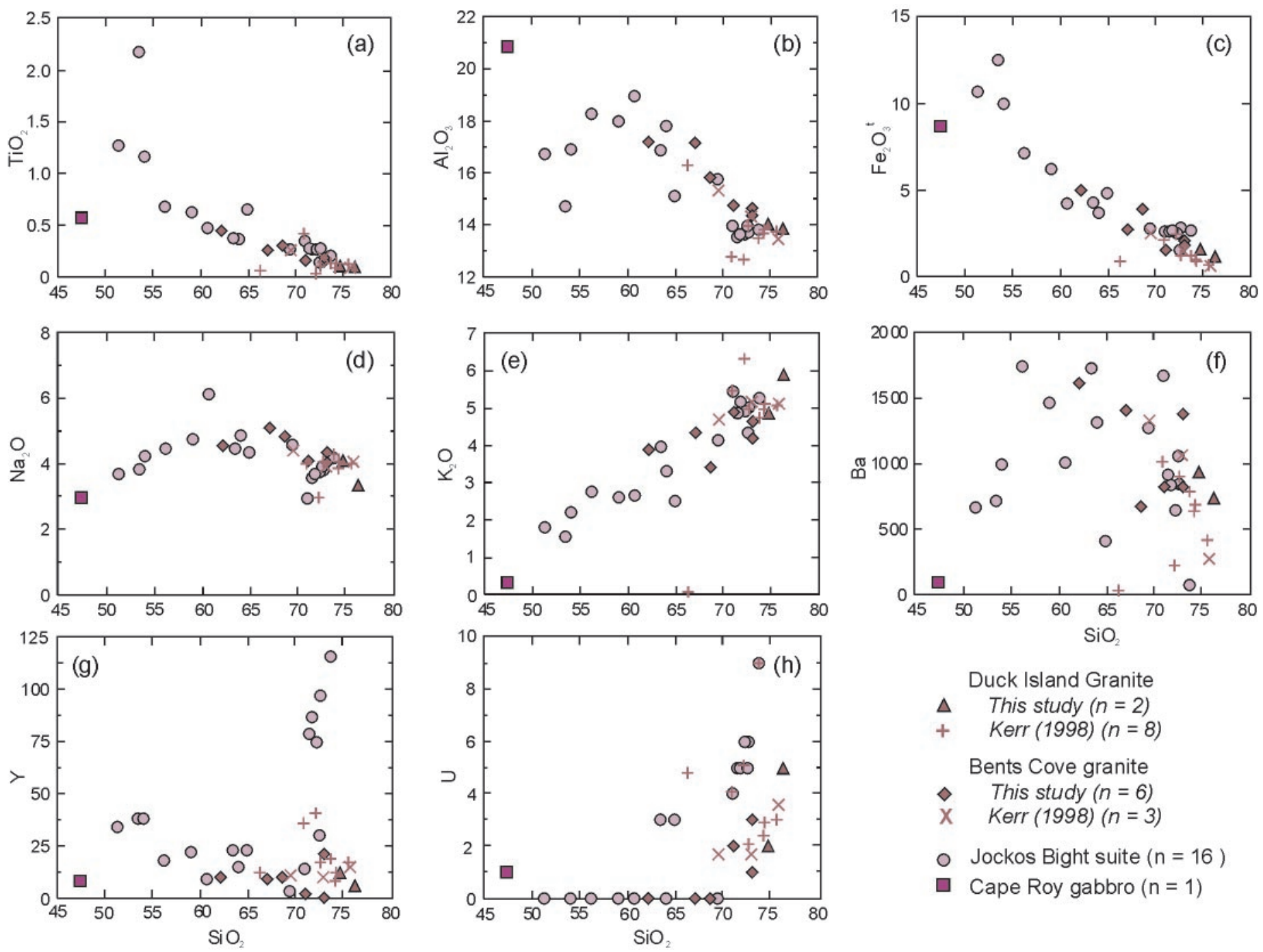

Fig. 8 Plots of $\mathrm{SiO}_{2}$ versus (a) $\mathrm{TiO}_{2}$, (b) $\mathrm{Al}_{2} \mathrm{O}_{3},\left(\right.$ c) $\mathrm{Fe}_{2} \mathrm{O}_{3}{ }^{\mathrm{t}}$, (d) $\mathrm{Na}_{2} \mathrm{O},(\mathrm{e}) \mathrm{K}_{2} \mathrm{O}$, (f) $\mathrm{Ba},(\mathrm{g}) \mathrm{Y}$, and (h) $\mathrm{U}$ for samples from the Labradorian plutonic units in the Kaipokok Bay area. Note that sample LAB98-229 from the Jockos Bight suite is off the U scale on (h) figure with $29 \mathrm{ppm}$ (Table 1). Uranium values shown at 0 are below the $1 \mathrm{ppm}$ detection limit.

Ma plutons also occur in the Kaipokok domain, as represented by the Drunken Harbour and Hares Islands units. Younger plutons of the Cape Roy-Jockos Bight-Duck Island-Bents Cove suites intruded gneissic rocks of the Kaipokok domain, as well as units in the Aillik domain. Hence isotopic studies would be an important follow-up from the data presented here.

\section{CONCLUSIONS}

The present study, combined with previous work, provides a significant database at a reconnaissance level for the major igneous units in the northeastern Kaipokok Bay area. Field observations and chemical data confirm that igneous rocks with ages of about $1800 \mathrm{Ma}$ and about 1660-1640 Ma occur in both the Kaipokok and Aillik domains of the Makkovik Province. The U-Pb age of $1800.6 \pm 2.3 \mathrm{Ma}$ for the Kennedy Mountain granite confirms the previously inferred age for the widespread Kennedy Mountain Intrusive Suite, and further emphasizes the importance of 1800 Ma magmatism in the Makkovik Province. More detailed study is needed in order to better understand the tectonic setting(s) and especially to investigate the sources and petrogeneses of these well exposed rocks.

\section{ACKNOWLEDGEMENTS}

Field studies and analytical work were funded by a Lithoprobe Supporting Geoscience research grant to N. Culshaw and S. Barr, and by a Natural Sciences and Engineering Research Council of Canada Discovery Grant to S. Barr. We are grateful to Nick Culshaw for introducing us to the geology of the Makkovik Province. We thank Samantha Pilgrim of Postville for her boating skills, patience, and bravery dur- 

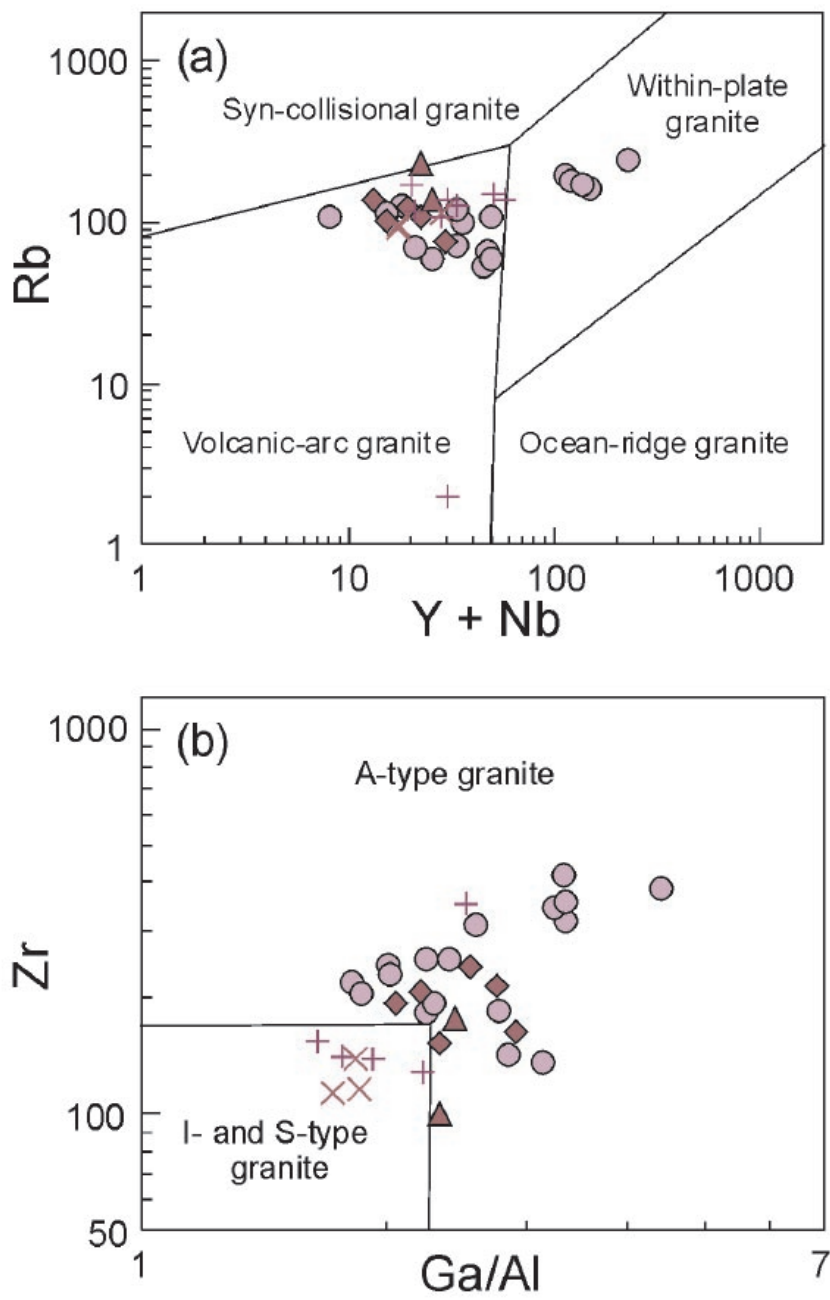

Fig. 9 Plots of (a) $\mathrm{Y}+\mathrm{Nb}$ versus $\mathrm{Rb}$ and (b) Ga/Al versus $\mathrm{Zr}$ for samples from Labradorian plutonic units in the Kaipokok Bay area. Symbols are as in Fig. 8. Fields in (a) are from Pearce et al. (1984) and in (b) from Whalen et al. (1987).

ing the at-times-harrowing field work for this project. We are grateful to journal reviewer Alana Hinchey for her very helpful comments and suggestions, which improved both clarity and content; her report on the Aillik domain was published after this manuscript was submitted, and enabled us to make substantial improvements during the revision process. John Ketchum provided helpful comments on the initial submitted manuscript, and joined as an author in order to include the Kennedy Mountain U-Pb age reported herein. We also thank Rob Fensome for his helpful editorial suggestions.

\section{REFERENCES}

BAILEY, D.G.1981. Kaipokok Bay-Big River, Labrador. Newfoundland Department of Mines \& Energy, Map 81-18, scale 1:100 000 .
Barr, S.M., White, C.E., Culshaw, N.G., and Ketchum, J.W.F. 2001. Petrology, age and tectonic setting of the Island Harbour Bay Plutonic Suite, Makkovik Province, Labrador. Canadian Journal of Earth Sciences, 38, pp. 441-463.

Clark, A.M.S. 1979. Proterozoic deformation and igneous intrusions in part of the Makkovik sub-province, Labrador. Precambrian Research, 10, pp. 95-114.

Cox, R.A., Wilton, D.H.C., AND KošLER, J. 2003. Laserablation U-Th-Pb in situ dating of zircon and allanite: an example from the October Harbour Granite, Central Coastal Labrador, Canada. The Canadian Mineralogist, 41, 273-291.

Culshaw, N.G., Ketchum, J.W.F., and Barr, S.M. 2000. Structural evolution of the Makkovik Province, Labrador, Canada: tectonic processes during 200 myr. at a Paleoproterozoic active margin. Tectonophysics, 19, pp. 961-977.

Culshaw, N.G., Reynolds, P., Sinclair, G.S., ANd Barr, S.M. 2002. Amphibole and mica ${ }^{40} \mathrm{Ar} /{ }^{39} \mathrm{Ar}$ ages from the Kaipokok and Aillik domains, Makkovik Province, Labrador: towards a characterization of back-arc processes in the Paleoproterozoic. Canadian Journal of Earth Sciences, 39, pp. 749-764.

ERMANovics, I.F. 1993. Geology of the Hopedale Block, southern Nain Province, and the adjacent Proterozoic terranes, Labrador, Newfoundland. Geological Survey of Canada Memoir 431, $161 \mathrm{p}$.

GANDHI, S. S. 1978. Geological setting and aspects of uranium occurrences in the Kaipokok Bay-Big River area, Labrador. Economic Geology, 73, pp. 1492-1522.

Gandhi, S.S., Grasty, R.L., And Grieve, R.A.F. 1969. The geology and geochronology of the Makkovik Bay area, Labrador. Canadian Journal of Earth Sciences, 6, pp. 1019-1034.

Gower, C.F., And Ryan, B. 1986. Proterozoic evolution of the Grenville Province and adjacent Makkovik Province in eastern-central Labrador. In The Grenville Province. Edited by J.M. Moore, A. Davidson, and A.J. Baer. Geological Association of Canada Special Paper 31, pp. 281-296.

Gower, C.F., AND Ryan, B. 1987. Two stage felsic volcanism in the Lower Proterozoic upper Aillik Group, Labrador, Canada: its relationship to syn- and post-kinematic plutonism. In Geochemistry and mineralization of Proterozoic volcanic suites. Edited by T.C. Pharaoh, R.D. Beckinsale, and D. Rickard. Geological Society of London Special Publication 33, pp. 201-210.

Gower, C.F., Flanagan, M.J., Kerr, A., and Bailey, D.G. 1982. Geology of the Kaipokok Bay - Big River area, Central Mineral Belt, Labrador. Newfoundland and Labrador Department of Mines and Energy, Mineral Development Division, Report 82-7, 77 p.

Hall, J., Wardle, R.J., Gower, C.F., Kerr, A., Coflin, K., Keen, C.E., and Carroll, P. 1995. Proterozoic orogens of the northeastern Canadian Shield: new information from the Lithoprobe ECSOOT crustal reflection seismic survey. Canadian Journal of Earth Sciences, 32, pp. 1119-1131.

Hinchey, A.M. 2007a. The Paleoproterozoic metavolcanic, 
metasedimentary, and igneous rocks of the Aillik domain, Makkovik Province, Labrador. Atlantic Geoscience Society Abstracts, Atlantic Geology, 43, p. 12.

Hinchey, A.M. 2007b. The Paleoproterozoic metavolcanic, metasedimentary, and igneous rocks of the Aillik domain, Makkovik Province, Labrador (NTS map area 13O/03). Current Research (2007), Newfoundland and Labrador Department of Natural Resources Geological Survey, Report 07-1, pp. 25-44.

KERR, A. 1994. Early Proterozoic magmatic suites of the eastern Central Mineral Belt (Makkovik Province), Labrador: geology, geochemistry, petrogenesis and mineral potential. Newfoundland Department of Mines and Energy, Geological Survey Branch Report 94-3, 149 p.

Kerr, A., And Fryer, B. J. 1994. The importance of late- and post-orogenic crustal growth in the early Proterozoic: evidence from Sm-Nd isotopic studies of igneous rocks in the Makkovik Province, Canada. Earth and Planetary Science Letters, 125, pp. 71-88.

KerR, A., AND WARDLE, R. J. 1997. Definition of an ArcheanProterozoic suture by isotopic studies of basement intersections from offshore wells in the southern Labrador Sea. Canadian Journal of Earth Sciences, 34, pp. 209-214.

Kerr, A., Krogh, T.E., Corfu, F., Schärer, U., Gandhi, S.S., AND KwoK, K.K. 1992. Episodic Early Proterozoic plutonism in the Makkovik Province, Labrador: U-Pb geochronological data and geological implications. Canadian Journal of Earth Sciences, 29, pp. 1166-1179.

Kerr, A., Ryan, B., Gower, C. F., and Wardle, R. J. 1996. The Makkovik Province: extension of the Ketilidian Mobile Belt in mainland North America. Geological Society of London Special Publication 112, pp. 155-177.

Kerr, A., Hall, J., Wardle, R.I., Gower, C.F., and Ryan, B. 1997. New reflections on the structure and evolution of the Makkovikian-Ketilidian orogen in Labrador and southern Greenland. Tectonics, 16, pp. 942-965.

Ketchum, J.W.F., Culshaw, N.G., and Dunning, G.R. 1997. U-Pb geochronologic constraints on Paleoproterozoic orogenesis in the northwestern Makkovik Province, Labrador, Canada. Canadian Journal of Earth Sciences, 34, pp. 1072-1088.

Ketchum, J.W.F., Barr, S.M., Culshaw, N,G., and White, C.E. 2001a. U-Pb ages of granitoid rocks in the northwestern Makkovik Province, Labrador: evidence for 175 m.y. of episodic syn- and post-orogenic plutonism. Canadian Journal of Earth Sciences, 38, pp. 359-372.

Ketchum, J.W.F., Jackson, S.E., Culshaw, N.G., and BARR, S.M. 2001b. Depositional and tectonic setting of the Paleoproterozoic Lower Aillik Group, Makkovik Province, Canada: evolution of a passive margin-foredeep sequence based on petrochemistry and U-Pb (TIMS and LAM-ICPMS) geochronology. Precambrian Research, 105, pp. 333-358.
Ketchum, J.W.F., Culshaw, N.G., and Barr, S.M. 2002. Tectonic evolution of the Makkovik Province - a synthesis. Canadian Journal of Earth Sciences, 39, pp. 711-730.

KroGH, T.E. 1982. Improved accuracy of U-Pb zircon ages by the creation of a more concordant system using an air abrasion technique. Geochimica et Cosmochimica Acta 46, pp. 637-649.

Pearce, J.A., and Cann, J.R. 1973. Tectonic setting of basic rocks determined using trace element analyses. Earth and Planetary Science Letters, 19, pp. 290-300.

Pearce, J.A., Harris, N.B.W., and Tindle, A.G. 1984. Trace element discrimination diagrams for the tectonic interpretation of granitic rocks. Journal of Petrology, 25, pp. 856-983.

Ryan A.B., KaY, A., ANd ERmanovics, I. 1983. The geology of the Makkovik Subprovince between Kaipokok Bay and Bay of Islands, Labrador. Newfoundland Department of Mines and Energy, Mineral Development Division, Maps 83-38 to 83-41, scale 1:50 000, with descriptive notes, $22 \mathrm{p}$.

SinclaIR, G.S. 1999. Geochemistry and argon thermochronology of the Upper Aillik Group and associated granitoid rocks in the Makkovik Bay area, Aillik Domain, Makkovik Province, Labrador. M.Sc. thesis, Dalhousie University, Halifax, 294 p.

Sinclair, G.S., Barr, S.M., Culshaw, N.G., ANd Ketchum, J.W.F. 2002. Geochemistry and age of the Aillik Group and associated plutonic rocks, Makkovik Bay area, Labrador: implications for tectonic development of the Makkovik Province. Canadian Journal of Earth Sciences, 39, pp. 731-748.

StACEY, J.S., AND KRAMERS, J.D. 1975. Approximation of terrestrial lead isotope evolution by a two-stage model. Earth and Planetary Science Letters, 26, pp. 207-221.

Wardle, R. J., ANd Bailey, D. G. 1981. Early Proterozoic sequences in Labrador. Geological Survey of Canada, Special Paper 81-10: 331-359.

Whalen, J. B., Currie, K. L., and Chappell, B. W. 1987. A-type granites: geochemical characteristics and discrimination. Contributions to Mineralogy and Petrology, 95, pp. 407-419.

White, M.V.W., And Martin, R.F. 1980. The metasomatic changes that occur with uranium mineralization in the nonorogenic rhyolites of the Upper Aillik Group, Labrador. Canadian Mineralogist, 18, pp. 459-479.

Wilton, D. H. C. 1996. Metallogeny of the Central Mineral Belt and adjacent Archean basement, Labrador. Newfoundland and Labrador Department of Mines and Energy, Geological Survey Mineral Resource Report 8, 178 p.

Winchester, J. A., AND Floyd, P. A. 1977. Geochemical discrimination of different magma series and their differentiation products using immobile elements. Chemical Geology, 20, pp. 325-343.

Editorial responsibility: Robert A. Fensome 


\begin{tabular}{|c|c|c|c|c|c|c|c|}
\hline $\bar{z}$ & 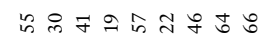 & 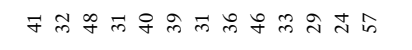 & if & $\infty$ & 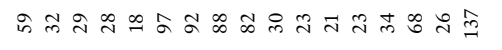 & मृत הิ & 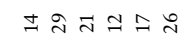 \\
\hline 8 & 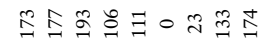 & 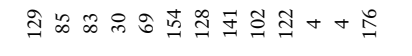 & 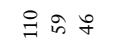 & \& & 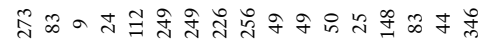 & îdo & F $\vec{\sim} \infty$ 的监 \\
\hline ت & 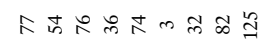 & 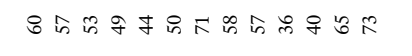 & $3 \approx$ in & \pm & 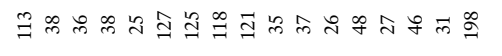 & $\infty i$ & 办 \\
\hline כ & nnomento ins & 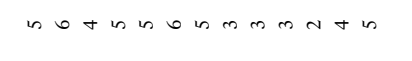 & $0+\infty$ & - & 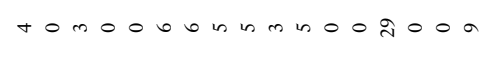 & ain & noomno \\
\hline 8 & 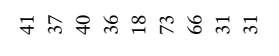 & 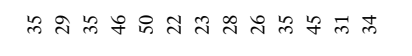 & $\therefore \pm \pi$ & 5 & 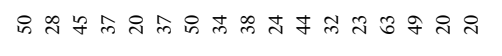 & 29 & 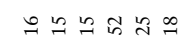 \\
\hline & $\pm n \pm \nexists 7 n=\infty 7$ & 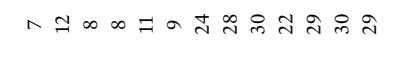 & के के in & - & 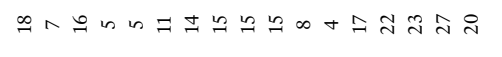 & is & సิ \\
\hline 广 & $\because-\infty \stackrel{\infty}{0} \circ \infty=0$ & $\infty \infty 9=+60008$ in 00 & $0+0$ & 6 & $0 N \bumpeq \rho n+0-m+0 \infty 0000$ & 00 & $000 n-a$ \\
\hline & 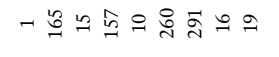 & 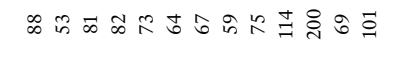 & $a \simeq 0$ & $\infty$ & 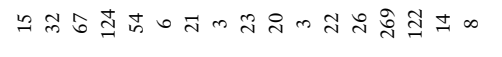 & $\circ+$ & 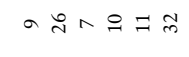 \\
\hline $\mathrm{z}$ & tor & onhNomonmoment & $0-0$ & 率 & 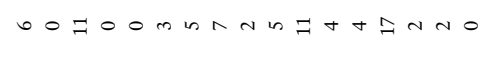 & no & 000000 \\
\hline च & $N \sin 0$ i t \pm 00 & $\therefore \sigma \nexists \triangle a=0$ in $\pm N \vec{\pi} \circ 0$ & 000 & $\stackrel{\infty}{\stackrel{\circ}{*}}$ & 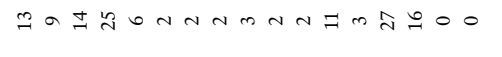 & $0-7$ & 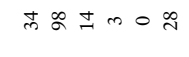 \\
\hline ㄴ. & 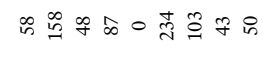 & 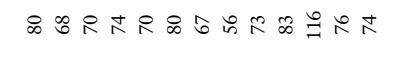 & 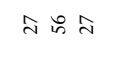 & 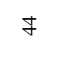 & 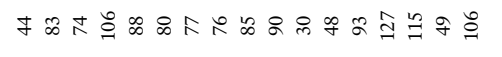 & $\infty$ ते & 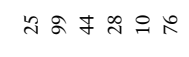 \\
\hline ङ & 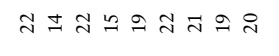 & 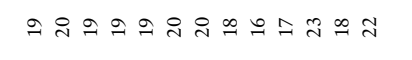 & 虽 & $=$ & 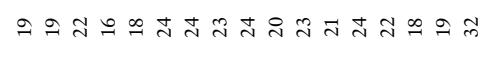 & $\stackrel{\infty}{\rightarrow}$ & 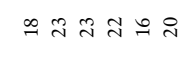 \\
\hline$\approx$ & 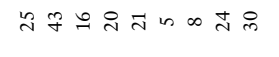 & 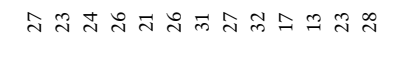 & $\stackrel{\sim}{\sim} \stackrel{\sim}{\mathrm{n}}$ & m & 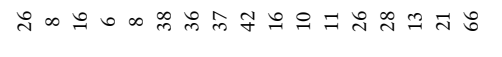 & is in & 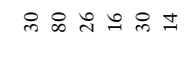 \\
\hline F & $\because \infty \pm 0 n-0 \bar{\lambda} A$ & $\simeq \simeq \cong \cong \simeq \simeq \simeq \cong$ 的 $\cong$ & 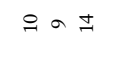 & $\circ$ & 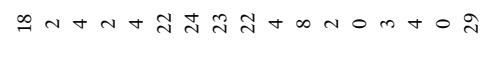 & 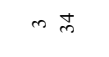 & $n \in N \infty=0$ \\
\hline$\hat{z}$ & 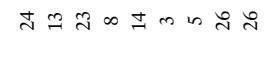 & 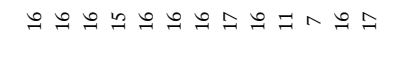 & $\widetilde{\lambda} \pi$ & $\infty$ & 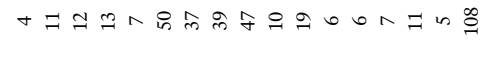 & $2 \simeq$ & $\simeq \cong \infty \approx n$ \\
\hline is & 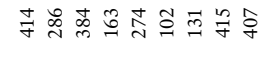 & 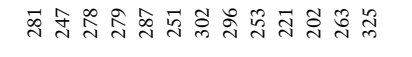 & 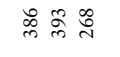 & I & 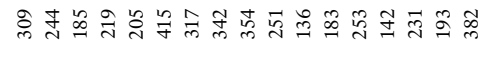 & $\stackrel{\infty}{\stackrel{2}{g}}$ & 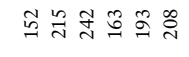 \\
\hline$>$ & 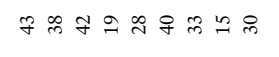 & 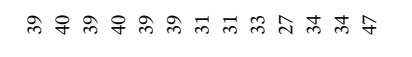 & पे & $\infty$ & 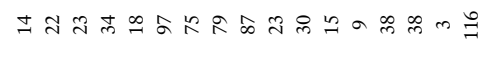 & $\simeq 6$ & $\circ \circ \sigma \vec{\lambda} N$ \\
\hline$\dot{\infty}$ & 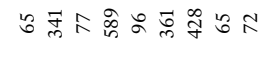 & 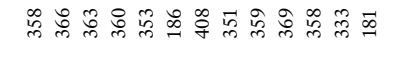 & $F$ 品 & $\stackrel{\infty}{\infty}$ & 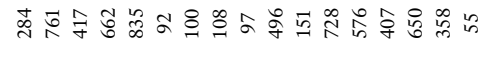 & : & 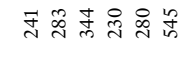 \\
\hline 우 & 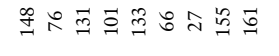 & 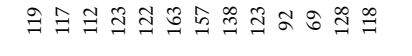 & 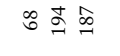 & \pm & 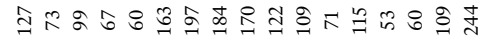 & $\stackrel{9}{q}$ & 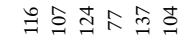 \\
\hline 䒢 & 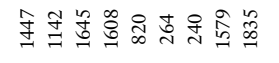 & 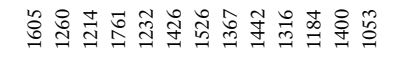 & 守范菺 & 2 & 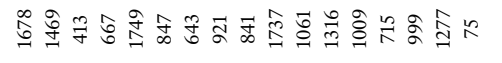 & कू रे & 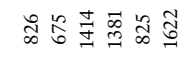 \\
\hline 蛋 & 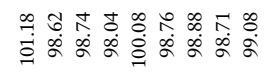 & 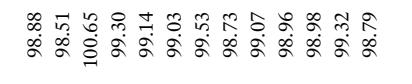 & 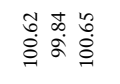 & 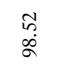 & 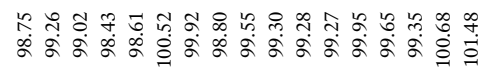 & 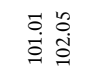 & \\
\hline ț & 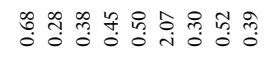 & 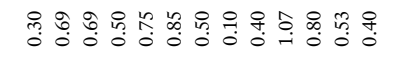 & 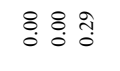 & స్ & 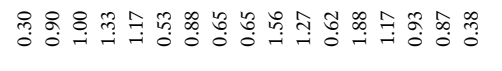 & दे : & 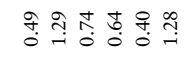 \\
\hline 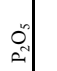 & 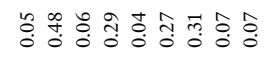 & 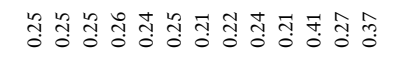 & $\stackrel{8}{0}: 0$ & $\stackrel{\text { og }}{0}$ & 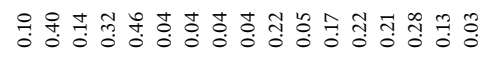 & $\stackrel{0}{0}: 0$ & 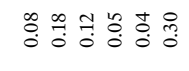 \\
\hline 일 & 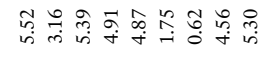 & 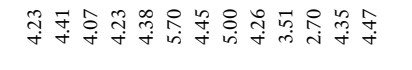 & 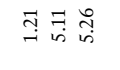 & 晜 & 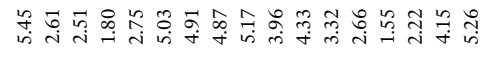 & 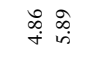 & 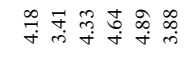 \\
\hline O্ & 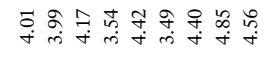 & 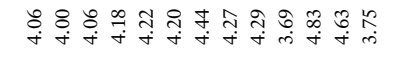 & 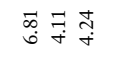 & बे & 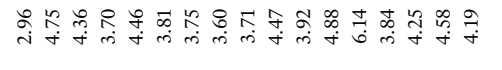 & 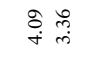 & 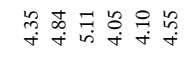 \\
\hline ‡ & 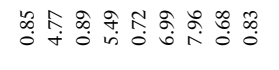 & 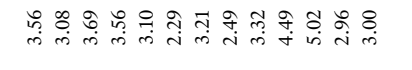 & 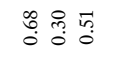 & సু & 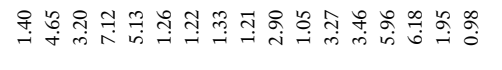 & 吕: & 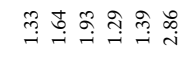 \\
\hline 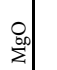 & 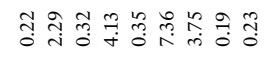 & 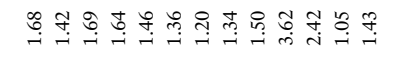 & $\dddot{9} 90$ & $\stackrel{\leftrightarrow}{i}$ & 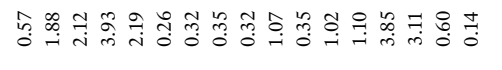 & $\stackrel{\infty}{0} \stackrel{\infty}{0}$ & 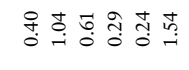 \\
\hline 妾 & 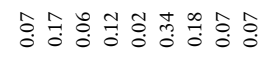 & F & 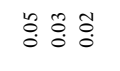 & ${ }_{0}^{7}$ & 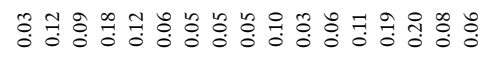 & 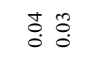 & 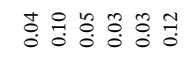 \\
\hline 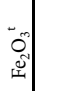 & 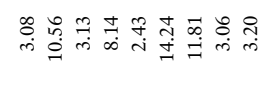 & 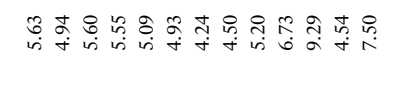 & 予 & $\underset{\infty}{\infty}$ & 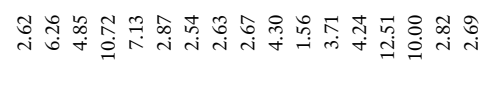 & $\stackrel{\circ}{\rightarrow}]$ & 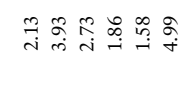 \\
\hline वी & & 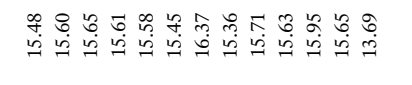 & 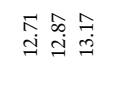 & 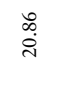 & 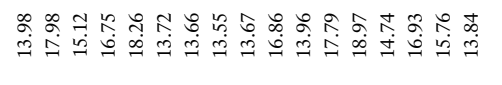 & 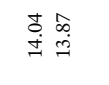 & 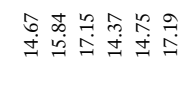 \\
\hline$\overbrace{}^{2}$ & 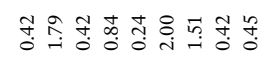 & 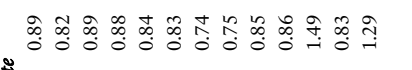 & 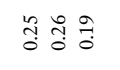 & so & 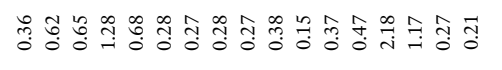 & 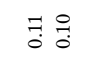 & 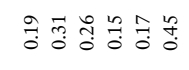 \\
\hline & & & & & 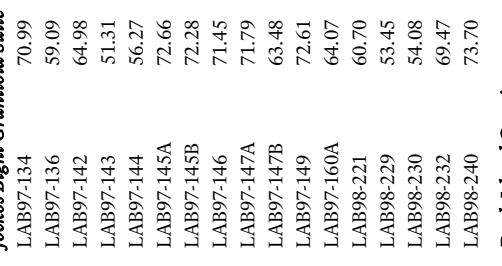 & $\int^{+1}$ & 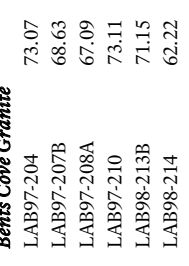 \\
\hline
\end{tabular}

